\title{
Atravessamentos pictóricos e afetivos em $A$ escuridão, o corpo vermelho e o fascínio
}

Pictorial and affective crossings in A escuridão, o corpo vermelho e o fascínio

Pedro Yugo Sano Mani Universidade de São Paulo yugo.sanomani@gmail.com 


\section{Resumo}

O artigo traz relato de um processo composicional musical que teve como fonte de materiais e ideias poéticas uma pintura da artista plástica Tomie Ohtake. Serão discutidos diferentes aspectos do trajeto criativo, de modo a serem ilustradas as ferramentas de escrita escolhidas, a definição de aspectos formais e as potências poéticas envolvidas. Além disso, serão comentadas algumas influências de outras fontes ligadas ao contexto da composição. Desta forma, busca-se mostrar uma possibilidade de trabalho para lidar com a problemática de criar música a partir de uma obra visual.

Palavras-chave: Processos criativos; atravessamentos artísticos; ferramentas composicionais; música e pintura.

\section{Abstract}

This article brings a repport of a musical compositional process which had a painting by the visual artist Tomie Ohtake as source of materials and poetic ideias. We will discuss different aspects of the compositional activity, so that the writing tools, the definition of formal aspects and the poetic potencials will be ilustrated. Besides that, some influencies from other sources connected to the context of the composition will be commented. This way we seek to demonstrate a possibility of work to deal with the problematic of creating music from a visual work.

Keywords: Creative processes; artistic crossings; compositional tools; music and painting

Mestrando em Sonologia - Processos de criação musical pelo programa de Pós-Graduação em Música da Universidade de São Paulo. Graduado em Música - Composição (bacharelado) pela mesma instituição. Desenvolve atualmente uma pesquisa acadêmica voltada às diferentes modalidades de percepção envolvidas na criação musical. Atua em diversos projetos artísticos ligados à composição, tais como música para teatro, trilhas para produções audiovisuais e música de concerto. 


\section{Introdução²}

Compor a partir de um objeto específico, seja uma poesia, uma escultura, um livro, uma cena, um fato etc., envolve inúmeras dimensões de escolha. Por um lado, é necessário eleger certos aspectos aos quais se apegar inicialmente, certos elementos norteadores que ajudem a germinar a ideia criativa a partir daquilo que se tem como fonte inicial. Por outro lado, parecem haver determinadas questões que "pedem para estar presentes", de tão fortes que são suas reverberações manifestas na fonte. E há também outras camadas que à primeira vista talvez não aparentem ser relevantes, mas que, ao longo de uma investigação aprofundada, revelam importância primordial para que aquilo sobre o qual trabalharemos exista.

O presente artigo apresenta o relato de um processo composicional musical gerido a partir de uma pintura, visando assim ilustrar um caso possível dentre as infinitas possibilidades disso ocorrer.

Em 2019 ocorreu o I Concurso de Composição Musical Tomie Ohtake, organizado pelo Instituto Tomie Ohtake em parceria com a Ocam (Orquestra de Câmara da ECA/ USP). Sua premissa foi a de estrear três peças musicais compostas a partir de pinturas específicas de Tomie Ohtake (1913-2015), artista plástica japonesa naturalizada brasileira cuja produção é de grande relevância no cenário artístico brasileiro e internacional dos séculos $\mathrm{XX}$ e $\mathrm{XXI}$.

Havia três categorias no concurso: 1) ensemble, 2) orquestra de cordas e 3) orquestra de câmara, sendo que cada categoria de composição deveria ser inspirada numa pintura determinada de Tomie Ohtake. O presente artigo traz relatos sobre o processo de criação da peça $A$ escuridão, o corpo vermelho e o fascínio, vencedora na categoria de orquestra de cordas, que foi escrita a partir de diferentes dimensões de atravessamentos com a obra Sem título (1987) de Tomie Ohtake.

Serão discutidos diversos momentos deste decurso criativo, buscando pôr em jogo tanto ferramentas de escrita quanto ideias poéticas e afetivas. Não é uma narrativa integral do processo (pois sequer imagino que seria possível haver consciência integral sobre isso) e não serão abordadas diretamente as experiências dos ensaios, apresentações e registros (que certamente foram muito ricas e somariam diversos outros assuntos). Sobre tais, seguem breves comentários.

Os ensaios e apresentações foram realizados por Gil Jardim (regente titular e diretor artístico da Ocam) e Enrico Ruggieri (regente assistente da Ocam).

Ao final de 2019, a Ocam lançou dois CDs: Sons sobre tons: criações musicais

\footnotetext{
2 O presente artigo é fruto da pesquisa de mestrado "A relação entre processos de solfejo e as estruturações da composição", financiada com bolsa regular Fapesp. Processo n 2018/14790-7, Fundação de Amparo à Pesquisa do Estado de São Paulo (Fapesp).

3 A seguir uma breve explicação sobre a produção da artista, presente no site do Instituto Tomie Ohtake (Disponível em: https://www. institutotomieohtake.org.br/o_instituto/tomie_ohtake (Acesso em: 15 mar. 2020): "A obra de Tomie destaca-se tanto na pintura e na gravura quanto na escultura. Marcam ainda sua produção as mais de 30 obras públicas desenhadas na paisagem de várias cidades brasileiras como São Paulo (Av. 23 de Maio, 1988; Anhangabaú, 1984; Cidade Universitária, 1994, 1997 e 1999; Auditório Ibirapuera, 2004; Auditório do Memorial da América Latina, 1988; Teatro Pedro Il em Ribeirão Preto, 1996; entre outras), Belo Horizonte, Curitiba, Brasília, Araxá e Ipatinga, feito raro para um artista no Brasil. Entre 2009 e 2010, suas esculturas alcançaram também os jardins do Museu de Arte Contemporânea de Tóquio e a província de Okinawa, no Japão. Em 2012, ainda, foi convidada pelo Mori Museum, em Tóquio, a produzir uma obra pública que se situa no jardim do edifício."
} 
sobre ideias visuais ${ }^{4}$ e Os segredos de Vera Cruz: música popular brasileira para gaita e orquestra $^{5}$. O primeiro deles é dedicado ao repertório de música contemporânea brasileira6 ${ }^{6}$ tendo peças de Valéria Bonafé ( $A$ menina que virou chuva) e Alexandre Lunsqui (Fibers, yarn and wire e Carreteis II), juntamente às peças vencedoras do Concurso de Composição Musical Tomie Ohtake: Afterimage, de Paulina Łuciuk, Dinâmica dos fluidos, de Wellington Gonçalves, e esta que descreverei a seguir ${ }^{7}$.

No processo de composição, dentre os tipos de atravessamentos da obra pictórica e a escritura da obra musical, surgiram tanto técnicas específicas de escritura, ligadas às potências energéticas presentes na própria pintura, quanto ideias poéticas desdobradas em diversas vertentes, estas ligadas aos afetos e sensações que a pintura gerara em mim.

É um relato que buscará se concentrar sobre pontos considerados relevantes do processo criativo, para assim discutir a composição musical feita a partir de uma obra visual ${ }^{8}$.

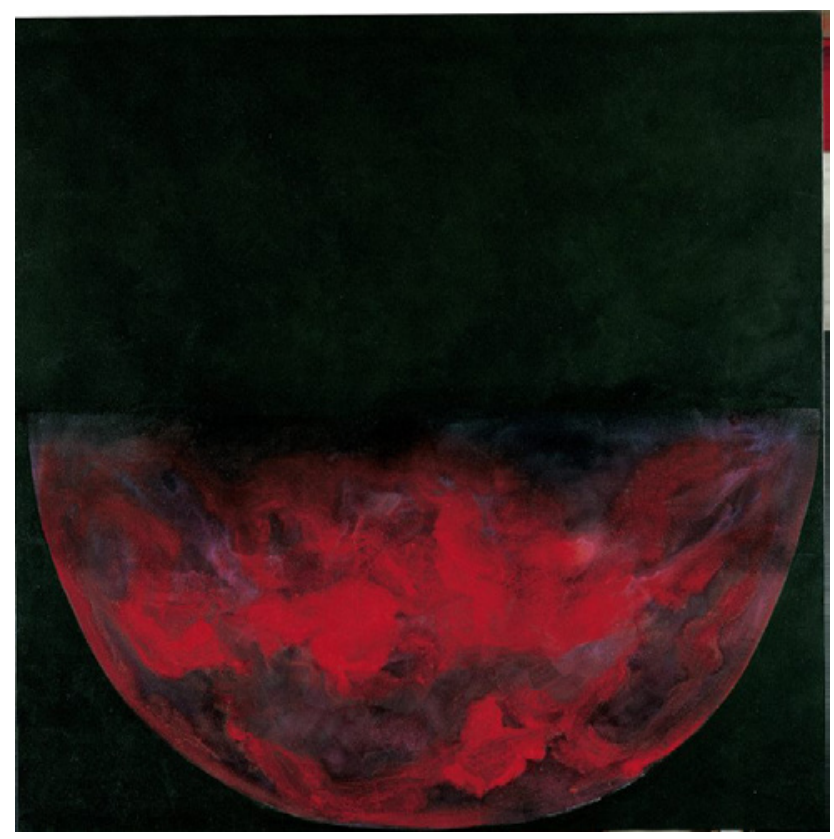

Fig. 1: Sem título (1987), pintura de Tomie Ohtake.

4 Disponivel em: https://open.spotify.com/album/ObzzycQbWE3QJCebXfRP7D e https://www.youtube.com/playlist?list=OLAK5uy_mmp2etxygakYVzhKarlpsC1rDhZMRssMo. Ambos acessados em: 15 mar 2020.

5 Disponivel em: https://open.spotify.com/album/5XBIPDkn9pJGYELvQ04JGJ e https://www.youtube.com/watch?v=wj3FGsmaJdQ\&list=OLAK5uy_lo9e336nm_MUQcA30D5u7sMJgAeLPpSVk. Ambos acessados em: 9 maio 2020.

$6 \quad 0$ segundo CD é formado por orquestrações de músicas do repertório popular brasileiro feitas por Gil Jardim e uma composição orquestral de Léa Freire. Há obras de Djavan, Edu Lobo / Chico Buarque, Herivelto Martins / Marino Pinto, César Camargo Mariano, Cartola, Léa Freire, Ivan Lins / Celso Viáfora / Ivano Fossati, Paulo Bellinati, Milton Nascimento / Márcio Borges.

7 Não é sempre que vemos uma iniciativa do gênero no ambiente musical brasileiro da atualidade, onde os cortes relacionados às atividades culturais e artísticas são cada vez maiores. Levando isso em conta, é preciso ressaltar a relevância desta iniciativa e agradecer às várias pessoas e instituições envolvidas. Agradecimentos ao Gil Jardim pela empolgante iniciativa e pela constante busca por dar voz a novos músicos; ao Instituto Tomie Ohtake, por ter abraçado a ideia do concurso e pelas parcerias constantes com a Ocam; ao Enrico Ruggieri, pela dedicação e empenho em reger a peça que escrevi, tanto nas apresentações quanto na gravação do CD; ao Estúdio Sala Viva - Espaço Cachuera! e ao Carlos (KK) Akamine pelo belo trabalho de gravação, mixagem e masterização; ao Filipe Fonseca pelo acompanhamento do processo de gravação; aos músicos da Ocam, pelo acolhimento, abertura e dedicação com que abraçaram as peças; à equipe técnica da Ocam, pela disposição e qualidade de seus trabalhos. 


\section{Investigando o que a pintura manifesta}

O processo iniciou com a simples observação da pintura, algo repetido várias vezes, de tempos em tempos relevando coisas antes não percebidas. O fato de não haver um título amplia as possibilidades de interpretação da obra, mas há algumas características básicas passíveis de formalização:

A cor preta existe em mais da metade da área total da imagem;

- Na Fig. 1 (que é exatamente a mesma imagem presente no edital do concurso) parece que, apesar do negrume estar bastante presente, ele não é chapado, pois apresenta nuances ${ }^{9}$;

Há um corpo vermelho presente na metade inferior da imagem;

Dentro das gradações de vermelho vemos tonalidades diferentes, indo de algo mais rosado a um vermelho sanguíneo;

No corpo vermelho é possível inferir gestos das pinceladas da artista;

O corpo vermelho assemelha-se a uma lua e sugere a possibilidade de ter uma forma total esférica, neste caso sendo parcialmente encoberta pelo negrume. Isto, porém, não é conclusivo. É possível imaginar que seja outra coisa que não uma lua, e seria também possível imaginar outra forma que não de uma esfera perfeita, caso de fato proceda a ideia de o corpo estar parcialmente encoberto;

Deixando de lado o que poderia vir a ser o corpo vermelho (se é que ele precisa representar algo $)^{10}$, vê-se que na metade inferior da imagem este corpo tem uma tendência que, vista de baixo para cima, é de crescendo;

No meio da imagem este crescendo se interrompe, há uma ruptura;

Há um eixo de simetria na pintura, de modo que a metade esquerda é simétrica estruturalmente à metade direita;

A economia de materiais é marcante.

Estas constatações, apesar de aparentemente óbvias, ofereceram diferentes estímulos e, ao longo da escritura, ganharam dimensões bastante profundas. Mas é claro que havia também outras questões em jogo, tais quais as sensações e os afetos suscitados pela pintura, os quais escapam radicalmente de uma formalização apenas racional: são questões que vibram em outros planos que não o do raciocínio apenas.

Quando Silvio Ferraz (FERRAZ, 2005, p.76-77) diz que ouvir um som é muito mais do que um simples estímulo auditivo, é reconhecendo a profundidade das relações que existem no processo de escutar. E estas relações também se aplicam às outras artes, tal

\footnotetext{
9 Não tive a oportunidade de ver a pintura ao vivo, de modo que não sei se de fato as nuances de preto são propositais ou se foram geradas por ocasião da tomada da imagem.

10 A busca por uma representação estanque pode levar a escolhas baseadas em referenciais estereotipados. Zampronha observa que referenciais e representações estereotipadas "tratam a arte como um processo de reconhecimento e não de percepção" (ZAMPRONHA, 2000, p. 240). Ou seja, mais do que perceber o que se constrói, busca-se reconhecer algo que já foi construído através dos hábitos do estereótipo. Disso ele reflete diversos aspectos que distinguem o reconhecer como mais característico do que chama de "paradigma tradicional" - vinculado à estética musical tradicional - e o perceber como mais característico do que chama "novo paradigma" - ligado às buscas da estética musical contemporânea de forma geral (idem, passim)
} 
qual a pintura, e aos nossos sentidos de modo global. Da citação abaixo entende-se que Ferraz também leva em conta que ver uma imagem é muito mais do que um simples estímulo visual. Os sentidos se comunicam, geram afetos, sensações, lugares... Observar uma pintura é também mover essa complexa rede de ressonâncias, abaixo descrita no terreno do musical:

\begin{abstract}
Ouvir um som, ser atraído por este algo que chamamos de som não é uma ação puramente auditiva. Nós vemos sons, sentimos a textura de sons, sentimos a pressão de sons em nossos ouvidos e em nossos órgãos, mas sentimos também seu cheiro, vemos os instrumentos que os produziram, sentimos a ação de um movimento de um corpo sobre outro. Tudo isto o que chamamos de sonoro. Mas, no plano da música, aquilo a que chamamos de escuta é mais do que sonoro. Ouvimos os sons discretos em notas, ou seja, o som marcado por pequenas inflexões as quais somos capazes de reproduzir cantando, assobiando, tocando um instrumento. $\mathrm{E}$, ao ouvirmos notas, vemos as mesmas notas; as vemos nos nossos dedos tamborilando um teclado imaginário; as vemos numa partitura, as dispomos de baixo para cima formando escalas, e com isso desenhamos pequenas relações entre notas, o que chamamos de frases musicais. E ainda vamos além em nossas escutas. Não ouvimos apenas os sons, as relações entre notas, ou ainda as relações entre sons (sons que se repetem ou sons que se transformam), escutamos tudo aquilo que vem com os sons. Não temos como ser surdos às relações que os sons tecem com nossas vidas; um grito, um chamado, um choro, um pedido, a voz humana, uma lembrança qualquer, uma paisagem sonora. E assim vai (FERRAZ, 2005, p.76-77).
\end{abstract}

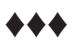

O impulso de imaginar um corpo esférico ou circular não é infundado. Se imaginarmos que uma forma é gerada por um fluxo energético, é possível inferir uma totalidade que "conclui" tal fluxo, caso não haja obstáculos para ele. Usemos o Practical Sketchbook de Paul Klee (1984) para ilustrar isso. Neste livro o artista plástico expõe um pensamento em que diversas forças estão em jogo. Na figura abaixo, por exemplo, vemos linhas "passivas" - que não oferecem resistência a um fluxo de energia, que o mantém seguindo o princípio da inércia - formando planos simplesmente por manterem tal fluxo: 


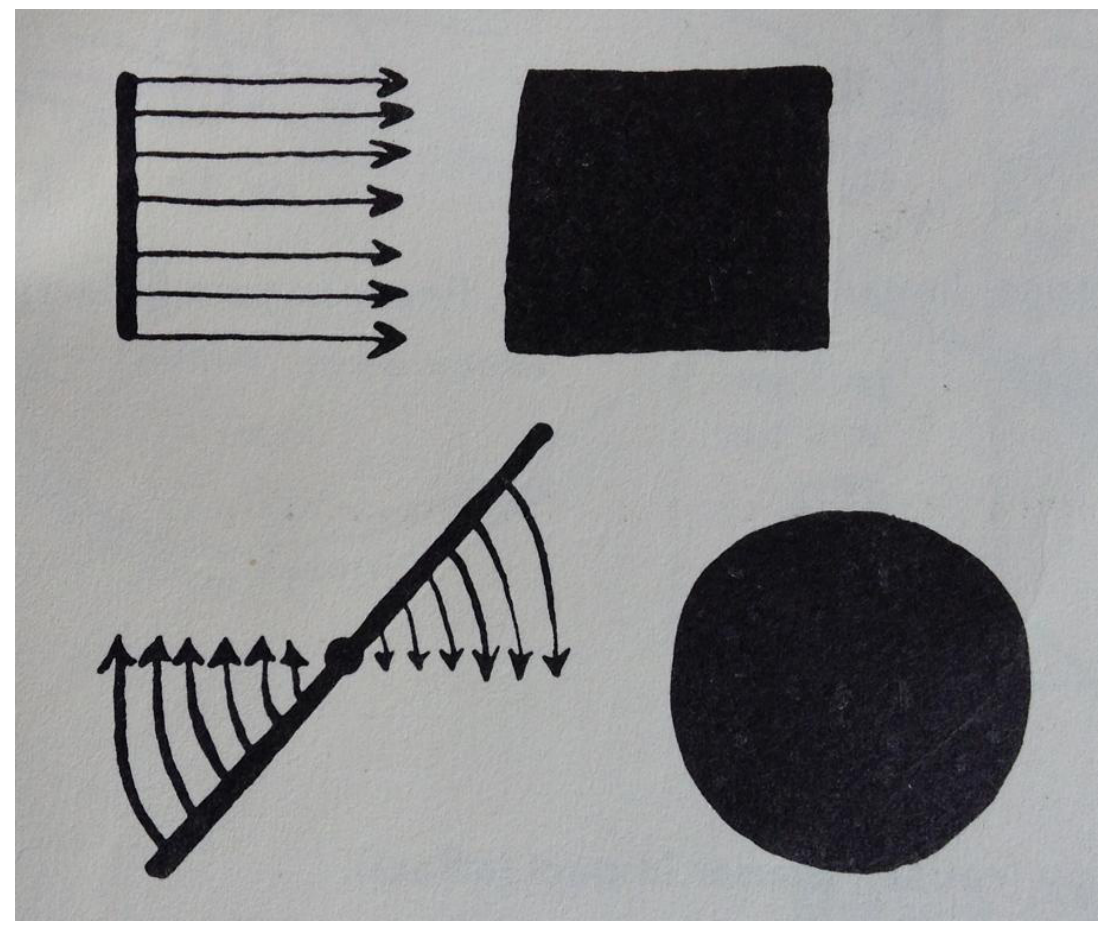

Fig. 2: A movimentação das linhas num dado sentido, nestes casos num deslocamento em linha reta (parte superior) e sobre um eixo central estático (parte inferior), é que faz com que um quadrado e um círculo se formem. Fonte: Klee (1984, p.19).

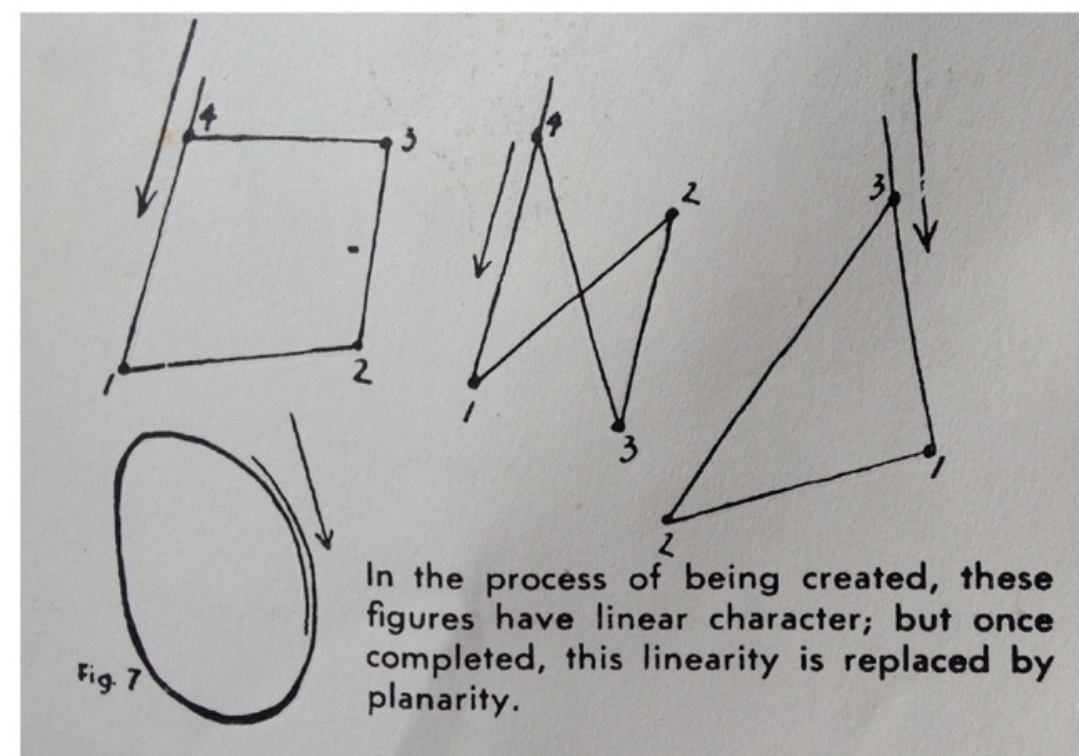

Fig. 3: Sobre a transformação de linhas em planos, Klee aponta: "No processo de serem criadas, estas figuras possuem caráter linear; mas uma vez completas, tal linearidade é substituída por uma planaridade". Fonte: Klee (1984, p.18).

Ou seja, quando linhas criam uma forma "fechada", tem-se um plano em vez de um conjunto de linhas. No caso especial do plano circular, seria possível inferir também uma tridimensionalidade, já que uma esfera mostraria um aspecto regular independentemente do ângulo pelo qual fosse observada. 
Tomie Ohtake tem diversas obras que investigam o círculo ${ }^{11}$, o que torna inquietante e interessante compor uma música a partir de uma de suas pinturas onde não se vê o círculo por inteiro, mas, sim, um semicírculo.

Compor a partir do que uma outra criação, realizada sobre outro meio, manifesta... À primeira vista isto pode aparentar ser uma espécie de relação dicotômica, em que dois meios opostos são postos frente a frente, confrontados. Mas a dicotomia não é o único viés que existe lá. Pelo contrário, podemos também ver um meio como modulador do outro. Por exemplo: o uso de mais de um suporte de criação também é uma via possível para lidar com imagens mentais e perceptivas que, num único suporte, poderiam apresentar dificuldades de organização. Nestas situações, a soma de suportes pode ampliar notavelmente a gama de ações possíveis.

Alexandre Ficagna, em sua tese de doutorado "Entre o visual e o sonoro: a composição por imagens" (2014), investiga objetivamente, no que tange à relação entre visualidade e música, as formas de conexão entre estes dois domínios. O autor tanto encontra exemplos de compositores cujos percursos composicionais lidavam com a visualidade em diversos prismas, tais quais György Ligeti, Edgard Varèse, Giacinto Scelsi, Salvatore Sciarrino e lannis Xenakis, quanto encontra artistas plásticos que exploravam a musicalidade presente na arte pictórica, tais quais Paul Klee e Wassily Kandinsky. A partir disso, ele também apresenta seus próprios processos criativos, nos quais o papel da visualidade se dá por meio de desenhos, que podem ser usados tanto na representação de um objeto sonoro detalhado quanto no desdobramento de eventos em grande escala, relação entre diferentes dimensões musicais etc.

Abaixo vemos uma situação composicional que se dá pela troca entre visualidade e sonoridade: um objeto sonoro que foi criado e manipulado por meio do desenho. É o objeto inicial de Escondido num ponto (2012), peça para flauta, sax alto, violoncelo e piano, composta por Ficagna através de um processo que une desenho e partitura musical. Após ter composto uma outra peça usando o desenho e a partitura de maneira experimental, o compositor conclui a reciprocidade entre os dois meios em que transitou: um exerce influência sobre o outro; o que se planeja num meio pode sofrer desvios ao tomar forma no outro meio; o diálogo entre ambos é contínuo e prolífico, tornando claras formas que apenas por um caminho poderiam ser amorfas ou mesmo invisíveis (FICAGNA, 2014, p.152-153). A partir disso, ele explora a "intermodulação entre meios" conscientemente na escritura de Escondido num ponto, transcurso que é relatado (além de outros) em sua tese de doutorado (FICAGNA, 2014, p.155-182).

\footnotetext{
11 No documentário Tomie, de Tizuka Yamasaki (2015. Disponível em: https://www.youtube.com/watch?v=x_cA_c6UcQg\&feature=emb_ logo e também no site do Instituto Tomie Ohtake: https://www.institutotomieohtake.org.br/o_instituto/tomie_ohtake, ambos acessados em 15 mar 2020), entre os 29' 30" e 30'20" há breves comentários sobre a exploração do círculo na obra de Tomie Ohtake.
} 


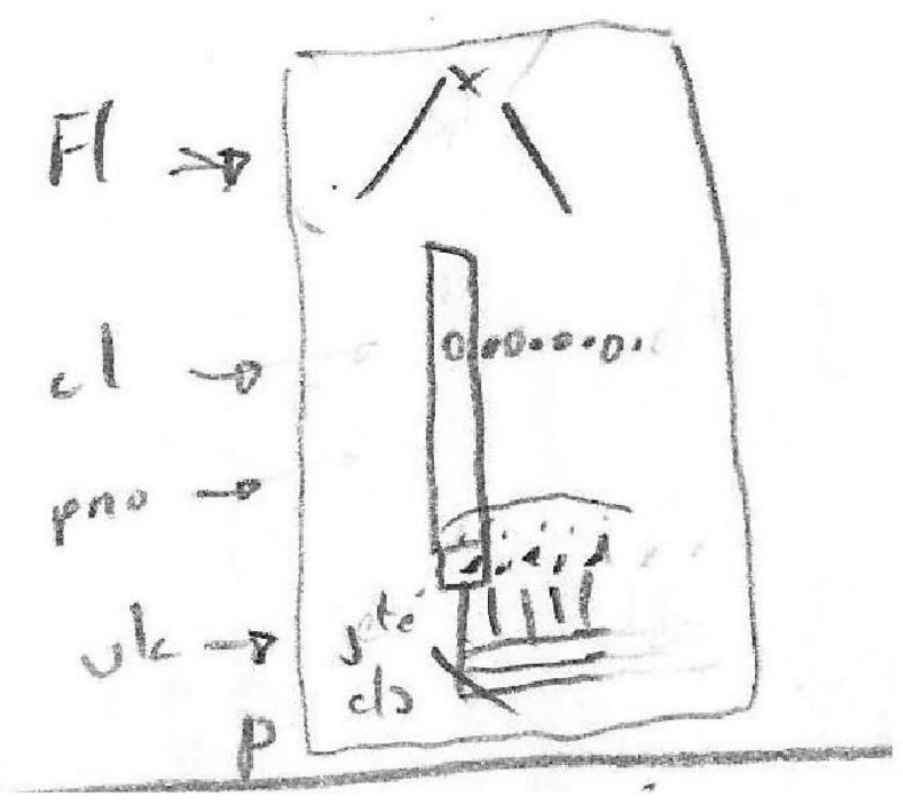

Fig. 4: Desenho de objeto sonoro complexo em Escondido num ponto. Fonte: Ficagna (2014, p.158).

O objeto sonoro desenhado acima é formado por: jet whistle na flauta, bisbigliando no clarinete, col legno battuto ricochet no violoncelo e ataque de um bloco harmônico no piano (FICAGNA, 2014, p.158). Tal objeto tem posteriormente suas partes deslocadas no tempo, mostrando assim características sonoras antes "escondidas" pela simultaneidade de eventos (um dos motivos para o nome da peça).

Há outras situações que podemos citar no que diz respeito ao intercâmbio entre os domínios da visualidade e da sonoridade como potência criativa. Anna Clyne, em sua composição orquestral Night Ferry ${ }^{12}$ (2012), fez sete telas utilizando técnicas pictóricas diversas paralelamente à composição da peça musical, a qual é dividida em sete seções formais análogas às telas, que, justapostas, formam uma linha de continuidade da esquerda para a direita. Dentre os estímulos criativos que a compositora relata, encontram-se também poemas de diferentes autorias ${ }^{13}$. Neste caso, temos curiosamente duas criações se dando ao mesmo tempo pela mesma pessoa, uma pintura e uma composição musical. Questões de timbre, densidade ou tessitura se associam a certas qualidades visuais, como combinações de cores, quantidade de elementos ou a região da tela onde estes se encontram e vice-versa. Contudo, apesar de terem sido realizadas paralelamente, as duas criações poderiam facilmente ser encaradas como autônomas por quem não tivesse conhecimento de suas circunstâncias.

Outra situação parecida, mas com resultado sonoro totalmente diferente, está nas criações de Chiyoko Szlavnics, que igualmente compõe músicas a partir de obras visuais,

\footnotetext{
12 É possível ouvir a peça na íntegra acessando: http://www.annaclyne.com/orchestra. Acesso em: 8 maio 2020.

13 Um breve texto da compositora sobre a peça e seus atravessamentos está disponível em: https://www.boosey.com/cr/music/Anna-Clyne-Night-Ferry/56273. Acesso em: 7 maio 2020. Um vídeo com comentários da compositora também está disponível em: https://www. boosey.com/podcast/Anna-Clyne-Anna-Clyne-Night-Ferry-with-the-CSO/13272. Acesso em: 7 maio 2020).
} 
as quais ela própria desenvolve (SZLAVNICS, 2006). O desenrolar temporal se dá igualmente no sentido da esquerda para a direita, mas o que chama a atenção em sua abordagem é o fato do desenho ser usado com a finalidade de manipular sons que se movem muito lentamente e com detalhes bastante minuciosos; é o meio que a compositora encontrou para lidar com as sutilezas de sonoridade que busca, de modo que, por meio de uma espécie de "tradução", imagens se transformam nos sons a serem trabalhados.

Todo processo composicional começa com a geração de um desenho, ou uma série de desenhos, em direção a uma peça específica para um ensemble existente ou um grupo de instrumentos. Quando surge um desenho forte e convincente, começo então um longo processo de tradução, o qual transforma imagens abstratas em sons ${ }^{14}$. (SZLAVNICS, 2006, p.38, grifos meus).

A abordagem do desenho a permite manusear sonoridades de longas durações com o uso de extensos glissandi e também a especificação de microintervalos, os quais fazem com que a escuta se concentre sobre os detalhes mais sutis do som (SZLAVNICS, 2006, passim $)^{15}$. É curioso observar que suas partituras mostram um plano bastante panorâmico: um trecho de vários segundos ou mesmo minutos pode ocupar apenas uma página ${ }^{16}$.

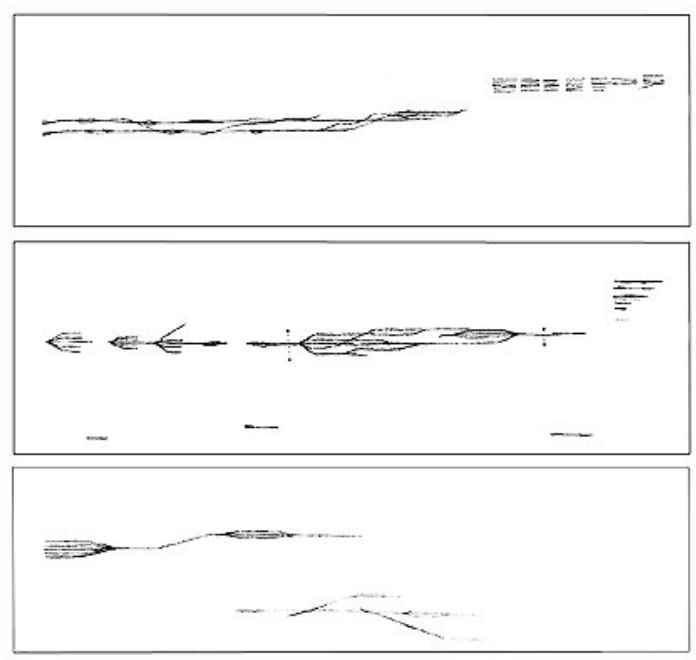

Fig. 5: Gradients of Detail (2005), obra visual de Chiyoko Szlavnics. Estes três desenhos deram origem à sua obra musical homônima para quarteto de cordas.

\footnotetext{
14 Original: "The entire composition process begins with the generation of a drawing, or a series of drawings, towards a specific piece for an existing ensemble or a group of instruments. When a drawing emerges that is strong and convincing, I then begin a long translation process, one which transforms the abstract images into sound".

15 No artigo em questão, Szlavnics mostra alguns de seus processos e comenta aspectos gerais de sua forma de compor, principalmente mostrando situações de sua peça Gradients of detail (2006, quarteto de cordas).

16 Cf. algumas de suas partituras em: http://www.chiyokoszlavnics.org/welcome.html. Acesso em: 10 maio 2020.
} 
Na produção de lannis Xenakis também temos várias situações em que a presença da visualidade é marcante, principalmente quando este faz uso do papel milimetrado. Mas um caso interessante é o de Mycenae Alpha (1978), peça eletroacústica realizada com o equipamento chamado UPIC, desenvolvido por Xenakis para compor através de uma interface inteiramente visual trabalhada por meio de traços realizados à mão, que são lidos da esquerda para a direita. Sobre o UPIC, Makis Solomos, musicólogo e pesquisador do qual uma das especialidades é a música de lannis Xenakis, aponta em seu livro De la musique au son: L'émergence du son dans la musique de XXe - XXle siècles (2013)17:

Trata-se de uma mesa de desenho sobre a qual, simplificando, desenha-se sucessivamente, com o auxílio de uma caneta eletromagnética, a curva de pressão do som e a "partitura". No primeiro caso, estamos no microtempo e o UPIC sintetiza os sons; no segundo caso, estamos no macrotempo e desenhamos a totalidade da obra (nesta segunda etapa, indicamos sobre a "partitura", através de um código particular, os sons escolhidos que já foram construídos na primeira etapa - sem falar dos envelopes de intensidade que a máquina também permite desenhar) [...]. Constatamos facilmente como este "sintetizador" é específico a Xenakis quanto ao método geral: ele faz uso do gráfico. O método de síntese também lhe é muito pessoal, já que se trata de desenhar diretamente a curva de pressão. Enfim, a terceira especificidade: com o UPIC, Xenakis pode caminhar em direção à unificação entre a microcomposição (síntese do som) e a macrocomposição (composição do todo), dado que o método é o mesmo (gráfico) [...]. (SOLOMOS, 2013, p.250) ${ }^{18}$.

Esta interface visual desenvolvida por Xenakis lhe permite, por um lado, trabalhar literalmente de forma manual as sonoridades e, por outro lado, unir micro e macrocomposição num só processo, em que ambas as dimensões se conectam.

Notemos que, nos quatro casos comentados, de Ficagna, Clyne, Szlavnics e Xenakis, a relação entre visualidade e temporalidade se dá numa lógica da esquerda para a direita, ou seja, a criação visual é percebida de forma análoga ao modo como lemos um texto. No presente relato, porém, foram investigados vetores que a pintura em si apresenta, como a questão da simetria entre as duas laterais ou a continuidade vertical que existe no corpo vermelho, de modo que a vetorização temporal não ocorreu horizontalmente.

Essas criações comentadas possuem também outra diferença contextual: elas não se baseiam inteiramente sobre uma criação específica de outra pessoa. Clyne utiliza diversas fontes, mas não busca necessariamente criar um discurso estritamente ligado a uma específica - elas são inspirações que darão forma às criações visual e musical -,

\footnotetext{
17

Há duas versões do livro: a impressa, que é a definitiva e tem todas as figuras, e a "versão do autor" que Makis Solomos disponibilizou na plataforma aberta HAL. Por conta do contexto de escrita do presente artigo, foi utilizada a versão do autor, na qual o número das páginas é diferente, resultado da ausência das figuras. Os números de página aqui especificados fazem sempre referência ao documento do autor em formato PDF.

18 Original: "Il s'agit d'une table à dessiner sur laquelle, pour simplifier, on dessine successivement, à l'aide d'un crayon électromagnétique, la courbe de pression du son et la « partition ». Dans le premier cas, nous sommes dans le microtemps et I'UPIC synthétise un son ; dans le second, nous sommes dans le macrotemps et l'on dessine la totalité de l'œuvre (dans cette seconde étape, on indique sur la « partition », par un code particulier, les sons choisis que l'on a déjà construits dans la première étape - sans parler des enveloppes d'intensité que la machine permet aussi de dessiner) [...]. On constate aisément en quoi ce « synthétiseur » est spécifique à Xenakis quant à la méthode générale : il fait appel au graphique. La méthode de synthèse lui est aussi personnelle, puisqu'il s'agit de dessiner directement la courbe de pression. Enfin, troisième spécificité : avec I'UPIC, Xenakis peut s'acheminer vers I'unification de la microcomposition (synthèse du son) et de la macrocomposition (composition de l'ensemble), puisque la méthode est la même (graphique) [...]".
} 
ao passo que Ficagna, Szlavnics e Xenakis se encontram numa proposta de criação que não se baseia sobre uma outra obra de outra autoria. Porém, todos estes casos tangem questões muito relevantes sobre a relação entre os domínios visual e sonoro, de modo que nutrem as temáticas postas em jogo neste artigo.

Já sobre uma criação feita a partir de outra, temos um caso interessante, de uma obra musical realizada a partir de uma criação textual-visual. Silvio Ferraz relata as soluções utilizadas para compor uma peça a partir de outra obra artística, o poema Algo, de Edgard Braga (FERRAZ, 2007). Aqui sua poética foi construída através do diálogo com o objeto de estudo, numa obra para coro a quatro vozes e percussão mista. Enquanto inicialmente sua tentativa era a de traduzir musicalmente o poema, o decorrer de suas elaborações foi para um rumo diferente, de lidar com as potências sonoras e musicais da visualidade, presentes no próprio poema, em interação com as potências táteis e texturais dos sons. O poema é de difícil leitura: "[...] um conjunto de dez gravuras em dez folhas soltas, cada uma com diversos rabiscos grafados a nanquim, letra-set e palavras, algumas formas, um grande caos aparentemente sem nenhuma ordem" (FERRAZ, 2007, p.92). O compositor aqui parte da ideia de tornar sonoras forças não sonoras, conceito integrante de sua poética em muitos momentos (cf., por exemplo, FERRAZ, 2005, p.69-71):

\begin{abstract}
A primeira tentativa de escrever a peça nada traz da versão final. Ali tentava-se a improvável tradução do poema. Traduzir o poema tentando trazer o "texto" à tona, seus significados difusos. É toda uma série de soluções para cada textura. Mas eis que em uma das páginas do rascunho tudo toma outro rumo. Foi preciso parar e recomeçar. Mas recomeçar buscando não no significado das palavras, no significado dos desenhos, no sentido que cada folha do poema apresentava, aquelas relações possíveis com a música, a sua tradução em música. Diria então que entrou aqui em jogo muito das leituras que na época eu vinha fazendo dos textos de Paul Klee. E a textura surgiu então como um caminho para se pensar a relação não mais entre o texto e a música, mas entre imagem visual e sonoridade, uma espécie de transdução na conversão de uma sensação tátil-visual em sua sinestesia sonora. A tatilidade do som em contraponto à sonoridade da imagem proposta por Braga (FERRAZ, 2007, p.94).
\end{abstract}

\title{
Com relação às notas musicais
}

As possibilidades de escuta que existem atualmente são plurais e, no caso da peça aqui descrita, busquei lidar com diferentes escutas ao longo do tempo: há momentos em que as notas musicais são relevantes no solfejo, mas a elas é somado o trabalho timbrístico. Também há escutas que se voltam aos jogos gestuais, outros que pensam em questões mais simbólicas, outros que trabalham sobreposições de camadas etc. São várias configurações de "escuta interna" (e que claramente influenciam a escuta efetiva da peça) que se cruzaram e se reorganizaram ao longo do processo.

No que tange às notas, queria escrever algo que não as "negasse" e que em certos momentos também abraçasse algumas sensações diatônicas. Mas que, por outro lado, 
tivesse estruturas intrincadas que, de tão preenchidas, possibilitassem sair do âmbito das notas musicais para entrar na dimensão dos timbres complexos.

Um ponto que me inquietava de início era a sensação das pinceladas de Tomie Ohtake ao examinar o corpo vermelho. Como fazer algo que converse com essa sensação?

Paralelamente a isso havia um descontentamento com a ideia de as notas musicais continuarem sendo tratadas apenas como unidades discretas, sendo alteradas sempre aos saltos. Se por um lado havia a busca por lidar com a sensação do pincelar e, por outro, havia a vontade de ver as notas musicais como unidades não puramente discretas, foi natural a conclusão de trabalhar com glissandi. Temos diversos exemplos de escrita que explora as potências do glissando, tais quais peças de Xenakis, como Syrmos (1959), Metastaseis (1953-1954), Pithoprakta (1955-1956), entre outras - a influência deste compositor, inclusive, se faz clara na escuta da peça aqui descrita. Os glissandi foram um meio para diluir as fronteiras entre notas, fossem vizinhas ou distantes, e trabalhar timbres, além de também modularem a escuta melódica.

Solomos aponta que Xenakis é o primeiro compositor a generalizar o uso do glissando, recurso que justamente "desconstrói a noção de nota [musical] e constitui uma sonoridade por si só"19 (SOLOMOS, 2013, p.224). Solomos explica que, para Xenakis, os sons granulares e pontuais são em realidade casos particulares dos sons em variação contínua - como os glissandi. Em certas situações, o compositor faz uso de cálculos para definir os "declives" dos glissandi, pensando principalmente em velocidades (onde um dado intervalo é dividido por uma dada duração), mas em outras situações é sobre o suporte do papel milimetrado que essas movimentações são construídas e trabalhadas (idem, ibidem). De todo modo, através de ambas as formas de manuseio do glissando, a dimensão das notas musicais se dissolve e o terreno efetivamente sonoro é tangido (SOLOMOS, 2013, p.224).

\section{$\leftrightarrow \diamond$}

No contexto da escritura de A escuridão, o corpo vermelho e o fascínio, eu analisava a peça de Rodrigo Lima Quando se muda a paisagem... ${ }^{20}$ (2008, orquestra de câmara), tal análise sendo parte das atividades de minha pesquisa de mestrado (atualmente em desenvolvimento). Mesmo que de forma inconsciente, agora vejo que a temática das matrizes harmônicas (LIMA, 2009) ${ }^{21}$, parte integrante da poética de Lima, se fez bastante presente no meu processo também, apesar de eu as chamar mais genericamente

\footnotetext{
19 Original: "Quant au glissando, il désagrège la notion de note et constitue une sonorité en soi".

20 Cf. os resultados das análises de Quando se muda a paisagem... em Mani e Ferraz (2019) e também na versão final da dissertação que o autor desenvolve atualmente, a ser finalizada em 2020.

21 Em sua dissertação de mestrado, intitulada Da nota ao som: explorando territórios harmônicos (2009), Lima estuda concepções de escrita do "som" em diferentes compositores do séc. XX com foco especial em Edgard Varèse. Um dos principais pontos estudados em sua pesquisa é a utilização de "matrizes harmônicas": uma matriz harmônica é basicamente uma estrutura sonora característica, a qual pode ser manipulada tanto harmônica quanto melodicamente de inúmeras formas. Pode ser, por exemplo, um acorde cujas propriedades são exploradas por meio de inversões, rotações, diferentes espacializações, transposições etc. O resultado é um conjunto de sonoridades que partilham certas características em comum, um "colorido próprio".
} 
de "campos harmônicos" nos rascunhos (os quais eram explorados vertical e horizontalmente, além de serem manipulados de várias formas, seguindo mais a proposta de matriz harmônica de Lima).

As matrizes harmônicas são estruturas pensadas como sonoridades que oferecem várias formas de manipulação, mas sempre conservando algumas características sonoras. Em Quando se muda a paisagem..., Lima compõe uma infinitude de configurações e de espaços sonoros com uma quantidade de materiais matriciais relativamente pequena. São as variações de materiais básicos e suas recombinações constantes que criam a riqueza inquestionável de sua peça, algo que ressoou também no meu contexto de criação.

Em A escuridão, o corpo vermelho e o fascínio encontram-se basicamente três estruturas sonoras em termos de organização de notas musicais:

1) sobreposições de $5 \mathrm{~J}$;

2) estruturas $A$;

3) estruturas B e C (ambas bastante próximas entre si, sendo tidas como duas formas de um mesmo colorido sonoro), as opções de B estando mais presentes do que as de $C$.

Vale apontar que essas estruturas não foram decididas com base em abstrações. Cada uma foi alcançada através de testes práticos ao piano, as "cores" delas sendo os fatores determinantes, e não suas simetrias ou seu enquadramento em determinados conjuntos predefinidos. Portanto, por mais que haja um resultado estrutural claro, constata-se que ele não se impôs no processo através de decisões estritamente racionais, pois foi fruto da busca por lidar com sonoridades encontradas empiricamente. Inclusive, as estruturas B e C foram achadas sem que eu soubesse de antemão que eram tão próximas entre si. Gostei de ambas e as anotei, mas apenas ao analisar posteriormente quais eram suas características é que percebi sua proximidade. Por um lado, isto deixou claro para mim que havia matizes ${ }^{22}$ específicos que buscava para a peça.

\footnotetext{
22 Sobre os termos "matriz" e "matiz", Rodrigo Lima esclarece: "A primeira trata-se da escolha de um 'bloco harmônico' de características intervalares específicas que sirva de modelo sonoro para uma obra musical. Matiz, por sua vez, seriam as gradações de sonoridades que a 'matriz harmônica' inicial sofre no decorrer da obra" (LIMA, 2009, p.43, nota de rodapé). Ao longo de sua dissertação, também observamos que uma matriz harmônica geralmente não é uma estrutura abstrata que se impõe, mas são coloridos sonoros que, por apresentarem marcas próprias na escuta, fazem com que suas estruturas matriciais se tornem fundamento basilar das sonoridades gerais.
} 


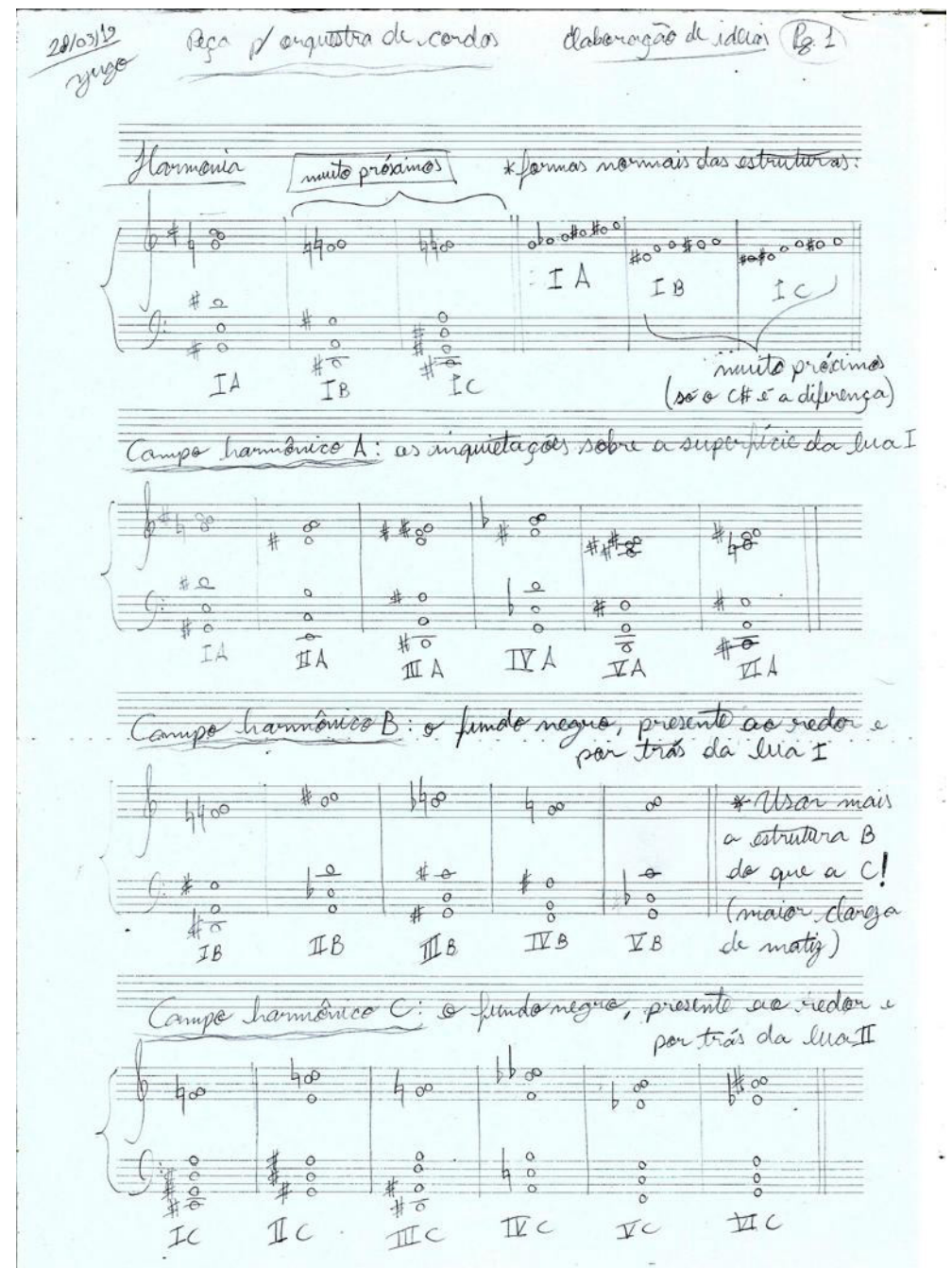

Fig. 6: Planejamento harmônico²3. A proximidade "acidental" entre os campos harmônicos B e C faz com que estes sejam tratados ao longo da peça como variações de uma mesma origem.

Queria coloridos que possibilitassem, quando desejado, um quê "quase diatônico" (que dialoga com a escuta tonal baseada em escalas diatônicas), mas que não o é. Foi, portanto, uma tentativa de lidar com mais de uma escuta, de manipulá-la de acordo com cada momento ${ }^{24}$. Por exemplo: se analisarmos o primeiro "acorde" da peça (cc.

23 Em algumas páginas dos rascunhos me refiro à "lua", mas não quis focar unicamente sobre essa concepção de representação. Por isso que ao longo do processo preferi usar o nome "corpo vermelho".

24 Meu contato com o compositor e pesquisador Gustavo Penha (2016) também se relaciona com esta proposta. Penha conta em sua tese de doutorado sobre o processo composicional de sua peça Per suonare in un teatro vuoto (2012, quarteto de cordas): "A peça foi construída a partir dessa ideia de organização temporal de variados modos de escuta, ou seja, da ideia de criar um fio condutor que faça com que a escuta varie de acordo com as diferenças de dinamicidades implicadas nos materiais que apreende enquanto interessantes. Assim, a peça se inicia propondo uma silenciosa, calma e distante escuta melódica de uma frase pentatônica simples, executada em harmônicos pelas cordas, e que vagueia pouco a pouco por entre os diferentes instrumentos pela técnica da distribuição timbrística. Aos poucos, algumas notas da melodia começam a permanecer umas sobre as outras fazendo com que a escuta, que até então focava prioritariamente sobre as mudanças melódicas, passe a se atentar também às cores singulares de alguns intervalos harmônicos que se distendem mais ou menos longamente por sobre a textura monódica pentatônica. É como se, com essas sobreposições de sons, a escuta melódica efetuasse um cruzamento com um modo de escuta de outra natureza, no caso um modo de escuta interválico, que se atenta às cores, aos pesos, às rugosidades e às variadas qualidades dos diversos intervalos harmônicos entre notas, alturas ou sons tônicos entre si. Assim, já em seu início, a peça propõe já um primeiro conflito entre modos de escuta, mais precisamente entre a escuta melódica e a escuta interválica harmônica. Em seguida, tendo a escuta melódica e a escuta interválica se consolidado como os modos principais de escuta da peça até então, um novo elemento é inserido, formado por pequenos ornamentos, fragmentos 
1-4), encontraremos o que poderia ser notado como B maior/menor (com ambas as terças maior e menor) com 7a e 9a acrescentadas. E este, por sua vez, é basicamente 0 mesmo acorde do final da peça. Mas as sonoridades do início e do fim, apesar de análogas em certos pontos, possuem diferenças concretas: no início todos os instrumentos têm um timbre "escuro" (tocando sul tasto, todos na $4^{a}$ corda e com surdina) e apresentam uma textura preenchida por glissandi; há certa clareza em termos de altura, os glissandi justamente sendo efetivos por conta disso. Já no final (a partir do c. 96, letra de ensaio G) a textura de tremolos tocados sul ponticello com a ponta do arco faz com que não sejam ouvidas notas musicais claras, mas, sim, sons "enevoados", difíceis de se distinguir; apesar do discurso formal (em que o início surge do nada e o final vai em direção ao nada) e da estrutura das notas ser parecida nos dois casos, as formas de escuta de cada momento possuem diferenças óbvias, principalmente no que tange ao trabalho sobre o timbre - questão de grande importância do início do fim.

As complexidades criadas com base nestes campos harmônicos são manuseadas de múltiplas maneiras. No início as movimentações em glissandi fazem com que uma gama de variações e nuances surja entre os acordes "estáticos" (pontos em que os sons se estabilizam). Foi uma tentativa de complexificar a escuta por meio de um recurso simples de escrita, também buscando diluir a dureza das notas musicais discretas. Por um lado, elaborei estruturas matriciais e solfejei certos pontos de modo melódico e harmônico; por outro lado, criei pontos de escape do solfejo baseado apenas em notas musicais, e, nisso, foram usadas formas de escrita que lidam com outros domínios do sonoro, como os glissandi, técnicas instrumentais com resultado sonoro mais complexo, transformações timbrísticas e improvisações (tratarei disso adiante).

O trecho entre os cc. 45-76 foi um desafio, porque é uma tentativa de fazer uma mudança gradual da escuta, como um "glissando que leva de uma forma de escuta a outra". Há uma carga gestual que se mantém constante e que paulatinamente vai acrescentando ataques mais ruidosos, até que eles se tornem tão presentes que saturem a sonoridade global.

Neste trecho há três camadas sobrepostas: 1), contrabaixos e violoncelos (registro grave), 2) violas e segundo divisi dos violinos II (registro médio), 3), primeiro divisi dos violinos II e violinos I (registro agudo). Todas as camadas têm movimentações derivadas de um único material, linhas e gestos que se remetem entre si, mas, apesar das três

\footnotetext{
motívicos e de frases melódicas, que faz com que a escuta seja atravessada por um modo de escuta heterofônico, ligado às pequenas variações que ocorrem em curtos intervalos temporais com relação ao desenrolar de uma linha melódica principal. 0 modo de escuta heterofônico [...] faz com que a continuidade e a linearidade da escuta melódica seja perturbada por outras escutas de coloridos, timbres, energias de transientes, perfis melódicos, ornamentos, que dão uma nova vida a materiais melódicos mais ou menos simples que têm constantemente renovados seus comportamentos e modos de variação pela exploração de uma pluralidade de qualidades sonoras, curvas dinâmicas, articulações, contornos e traçados motívicos, que põem a memória curta a operar intensiva e continuamente na escuta através de um processo em que a apreensão de novos elementos não ocorre sem que elementos anteriores sejam esquecidos e apagados da memória. É assim, portanto, que a primeira parte da peça se consolida, iniciando pela proposição de uma escuta melódica que se desenrola vagueando por entre os instrumentos até cruzar mais adiante com uma escuta interválica e, ainda mais à frente, ser perturbada por uma escuta heterofônica" (PENHA, 2016, p. 112-113).
} 
"caminharem juntas" - com uma sensação temporal semelhante -, cada uma age em lugares diferentes do tempo. E cada camada se baseia sobre um acorde do campo harmônico A (Fig. 6). É, portanto, um só campo harmônico, mas com três camadas fazendo estruturas distintas dele em sobreposição. E, da mesma forma, uma só ideia musical, mas com três registros simultâneos e três manifestações distintas de um mesmo tempo.

Já a ideia de lidar com essas camadas "iguais, mas diferentes" veio da pintura, do corpo vermelho repleto de pinceladas que se sobrepõem. É precisamente por isso que intitulei esta seção (que abarca os compassos descritos acima) como "Inquietações em vermelho". Uma das formas de deixar mais claras as ideias afetivas envolvidas na composição foi a utilização de títulos para as seções. Isso não busca "guiar" a escuta ou a interpretação para algo rígido e monofacetado, mas pôr em jogo sugestões que podem gerar ressonâncias internas nos intérpretes.

Na figura abaixo há anotações dentro de pequenas "caixas", tais quais "sl1 i, IIA", "sl2 r, IA", "sl1 o, IIA" etc. Essas anotações foram uma guia para que houvesse sempre consciência sobre a organização dos materiais em jogo. Seu funcionamento se dá da seguinte maneira:

"sl1" ou "sl2" se referem ao envelope melódico das camadas. Na Fig. 9, que consta adiante, há no centro da imagem o escrito "material da superfície da lua 1", enquanto na parte inferior da imagem consta "material da superfície da lua 2". As letras "sl" se referem a esses materiais da "superfície da lua25" (pois, pegando as iniciais de "superfície" e "lua", temos "sl"). Já os números 1 e 2 ("sl1" ou "sl2") dizem respeito a qual dos dois materiais melódicos da imagem será utilizado no trecho, da metade superior (1) ou da metade inferior (2) da Fig. 9;

"o", "i", "r" e "ir" se referem aos recursos que a escrita musical oferece ${ }^{26}$ de inverter e retrogradar materiais, que se encontram num vasto repertório musical. Deste modo, "o" = original, "i" = invertido, "r" = retrógrado e "ir" = invertido retrógrado; os algarismos romanos seguidos da letra " $A$ " (IIA, IA etc.) se referem às estruturas da Fig. 6 que são utilizadas em cada camada. Portanto, dentro de uma dada camada, se estiver escrito, por exemplo, IIIA, isto quer dizer que tanto vertical quanto horizontalmente as notas desta camada serão pertencentes à estrutura IIIA.

\footnotetext{
25 Faço aqui a mesma observação da nota de rodapé nº 23.

26 Coloco que são recursos "oferecidos" pela escrita musical por encarar que o suporte de criação possibilita certos procedimentos mais diretamente, enquanto outros não. Cf. em Delalande (2001, p. 32-50) os conceitos de "paradigma tecnológico" e "suporte de criação". Na música composta sobre partitura há "procedimentos de escrita" que se manifestam visualmente, tais quais retrogradação, contraponto, condução de vozes; em suma, o desenvolvimento de materiais horizontais e superposições verticais. Tudo isto se deve aos recursos da escrita, que propiciam determinadas práticas criativas (DELALANDE, 2001, p.32-33) - portanto, certas formas de escritura.
} 


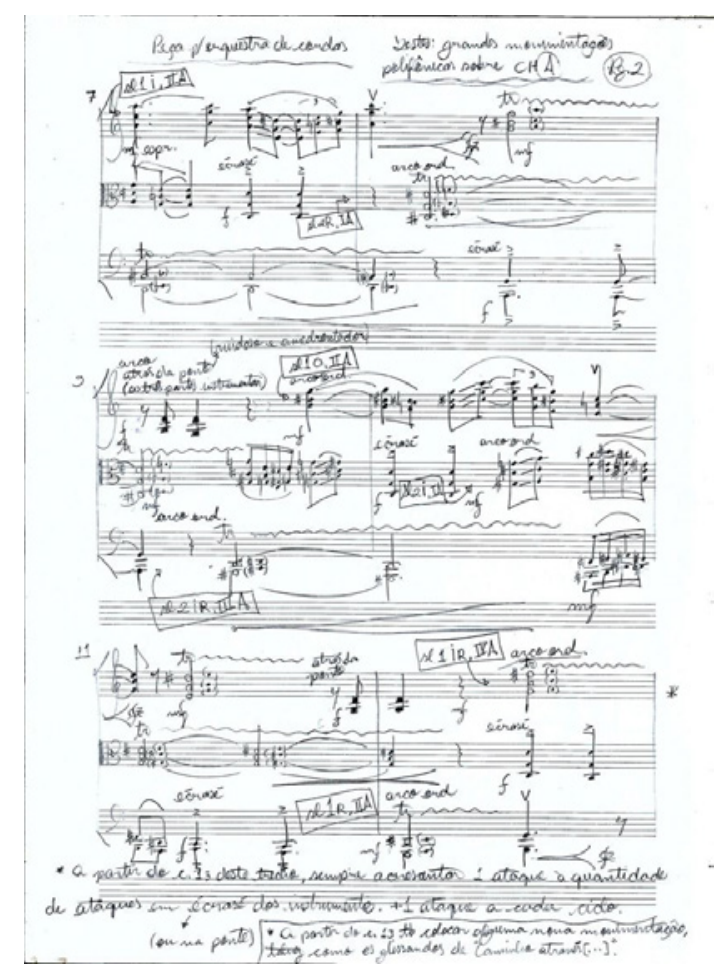

Fig. 7: Página dos rascunhos referente aos cc. 54-5927.

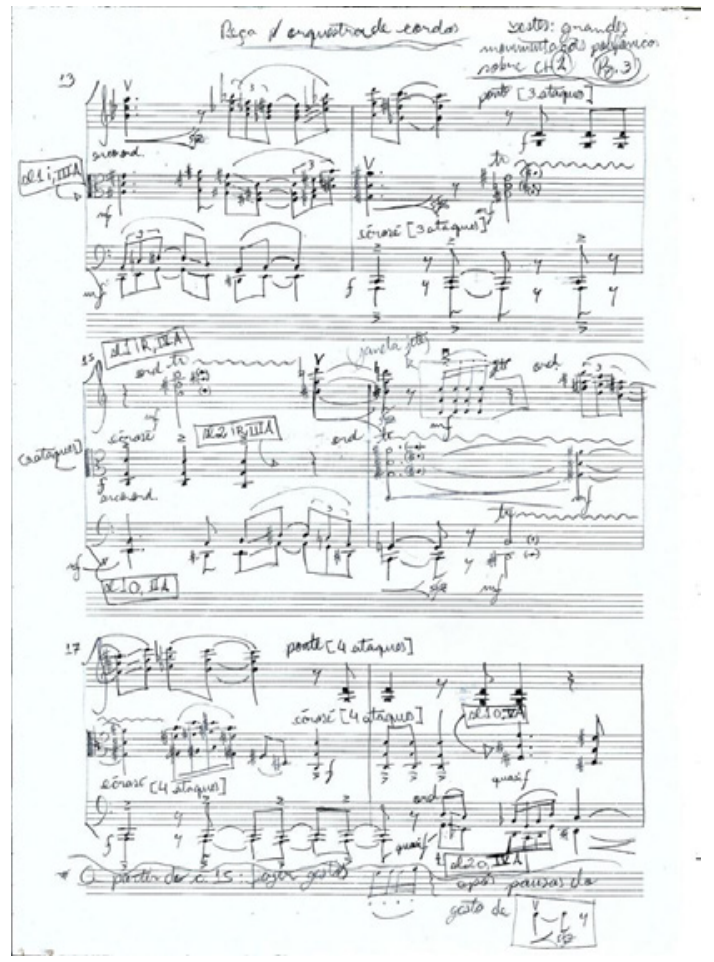

Fig. 8: Página dos rascunhos referente aos cc. 60-65 da partitura editada (presente nos anexos). 57 (c. 10 dos rascunhos, já que neles a contagem era sempre reiniciada a cada seção formal). No canto superior direito, o escrito "Testes: grandes movimentações polifônicas sobre CH A" diz respeito à exploração das três camadas de eventos (cada camada sendo una, mas com mais de um registro), as quais utilizam o Campo Harmônico A (cf. Fig. 6). 


\section{Quanto aos materiais básicos}

A economia de materiais da pintura me fez optar por explorar materiais musicais também econômicos, buscando criar as diferentes seções sempre revisitando as mesmas origens. Além disso, conforme explicado acima, a escritura se deu paralelamente à análise de Quando se muda a paisagem..., de Rodrigo Lima, algo que atravessou o processo criativo consequentemente. A maneira como Lima cria tantas variedades a partir de materiais mínimos me surpreendeu, pois à primeira vista a partitura de sua peça para orquestra de câmara parece conter uma enormidade de materiais novos a cada instante. Porém, todos os materiais possuem alguma forma de conexão entre si, e, além disso, podemos encontrar muitas variações de uma mesma ideia em vários contextos, e outras variações de outra ideia se sobrepondo às variações da primeira, e a sobreposição de ambas faz com que surja uma nova ideia etc. É uma forma de pensar em que tudo se conecta, seja de modo claro ou subjacente.

Após alguns testes, fossem ao lápis ou ao piano, pensando na questão da economia de materiais, escrevi a primeira linha melódica da peça, a qual é o primeiro solo que aparece na música, tocado pela viola. Neste ponto as estruturas matriciais harmônicas ainda estavam sendo esboçadas de maneira paralela. Houve uma coincidência entre esta linha e o primeiro acorde criado (que, conforme a Fig. 6, seria o IIB com uma disposição variada das notas e acréscimo de Fá\#). Este acorde se relaciona com um B maior/ menor com 7a e 9a , enquanto a linha inicia na nota Si e termina em Fá\#, além da maioria de suas notas pertencer à tonalidade de B menor. Mas não queria fazer linhas melódicas sobre acordes tonais apenas, pois acabaria entrando numa tendência bastante forte ligada à tradição tonal, algo do qual queria fugir, pelo menos em parte.

Foram feitos também testes usando o mesmo envelope melódico e rítmico da linha sobre outras configurações harmônicas. Paralelamente à definição da estrutura harmônica, fiz testes usando este envelope melódico/rítmico sobre os acordes dos campos harmônicos, de modo que nestas situações a linha melódica apenas usasse notas de um acorde específico. Com isso, foram criadas algumas possibilidades de coleções de linhas melódicas. Além disso, testei usar inversões e retrogradações da linha, recurso que se fez bastante presente na versão final (Fig. 7 e 8). 


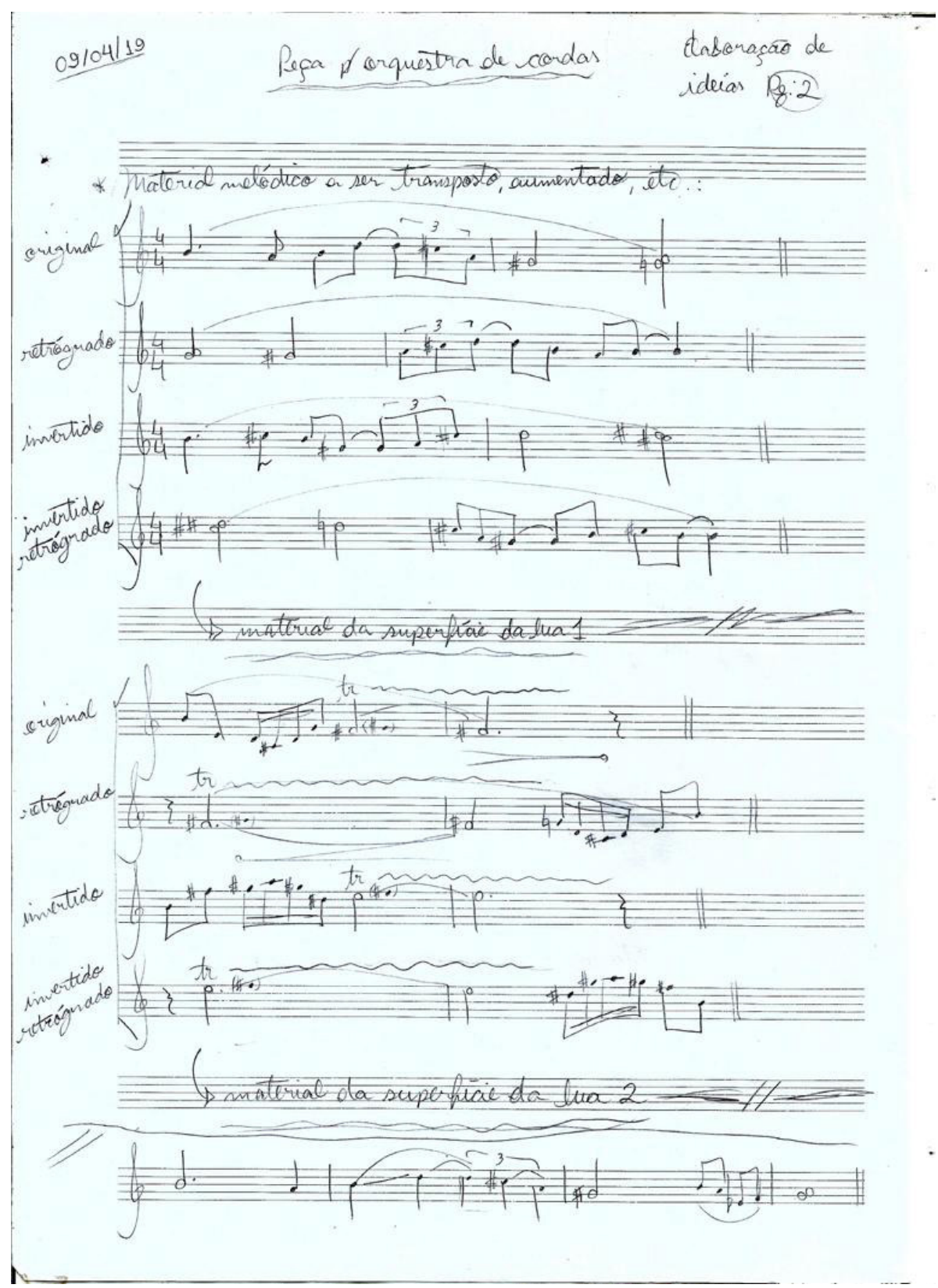

Fig. 9: Variações básicas da linha melódica criada (que aqui é dividida em duas frases). Na parte inferior da figura, um rascunho de possível variação do material melódico original.

Assim, partindo de uma linha de quatro compassos, foi criada uma coletânea de várias linhas e possibilidades de desdobramentos. Este princípio de, a partir de algo econômico, criar variações usando inversões e/ou retrogradações, tem inúmeros exemplos no repertório musical ocidental, seja em peças com seções retrogradáveis da Idade Média, seja na criação de uma complexa rede de atravessamentos no serialismo integral ${ }^{28}$ (além de várias outras opções). 

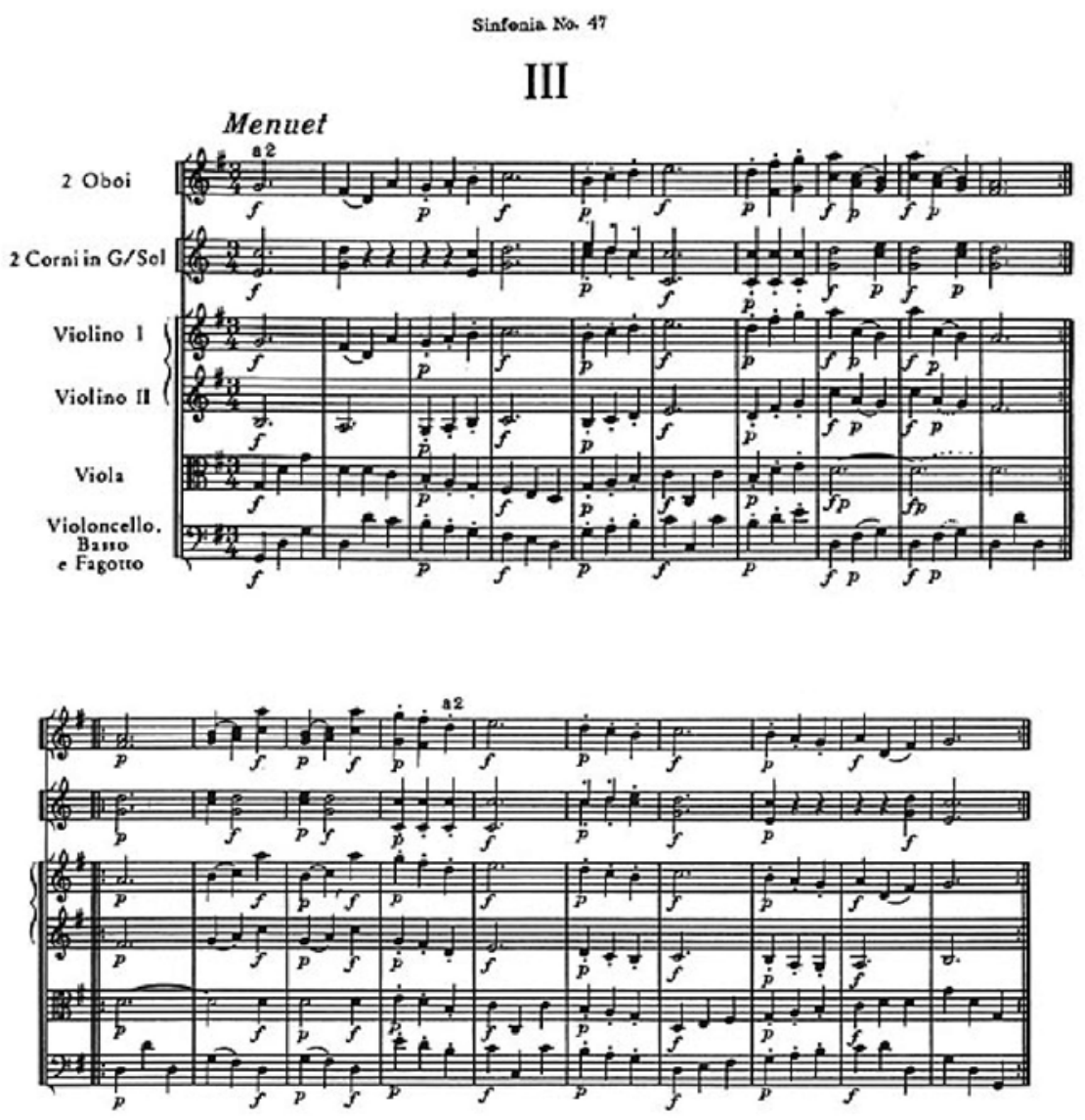

Fig. 10: Sinfonia $n^{\circ} 47$ de Joseph Haydn, $3^{\circ}$ movimento ${ }^{29}$. Um exemplo de retrogradação ${ }^{30}$.

No caso desta peça, eu desejava criar um aspecto reconhecível pela escuta, não sendo apenas observável pela análise da partitura. Também não deveria ser uma estrutura rígida, mas, sim, uma identidade sonora que pudesse ser percebida de modo consciente em muitos momentos (e subjacente em outros). Ao longo do processo, mais do que pensar nos intervalos da linha, o envelope melódico geral é que virou o foco do solfejo. Ou seja, ao invés de pensar em notas que formam uma melodia composta por intervalos, o solfejo lidou com envelopes melódicos que possuem perfis próximos, criando assim uma identidade sonora presente, mas ao mesmo tempo um pouco mais "enevoada" do que seria numa conservação estrita dos intervalos originais. O desenho da melodia se tornou mais relevante do que seus intervalos um a um.

É curioso relatar que me peguei constantemente cantando as melodias, os envelopes melódicos e os gestos da peça. Ou seja, estava "subvocalizando-os": cantar abertamente, cantar de maneira aproximada ou mesmo respirar ao imaginar o som que será feito, tudo isso são possibilidades de subvocalização. Arnie Cox (2011) explica que “normalmente somos capazes de representar alturas, ritmos, intensidades (no senso 
estrito de força acústica) e, até certo ponto, o timbre, de qualquer fonte instrumental via subvocalização mimética" (COX, 2011, p.7) ${ }^{31}$.

Subvocalização mimética inclui qualquer imagem motora e ativação motora ligada à musculatura vocal. Tenha em mente que não é preciso ser intencional ou consciente, pode ser simplesmente cantar junto ou indiretamente, envolvendo apenas a respiração no tempo [...], ou os variados tipos de ações da garganta e/ ou língua e/ou lábios ${ }^{32}$. (COX, 2011, p.9).

\section{Quanto à forma}

A peça como um todo teve vários pontos decididos ao longo do processo, não sendo resolvidos de antemão. Por outro lado, o aspecto formal panorâmico teve, neste caso específico, estruturas bem definidas escolhidas com antecedência. Fiz um pequeno mapa formal, de modo a organizar a sucessão de eventos e suas respectivas durações, além de poder especificar algumas questões pontuais relevantes para cada momento. Na figura abaixo vemos uma divisão geral em três partes. As primeiras duas partes equivalem a dois "crescendos formais" que serão comentados adiante; a terceira parte comporta o fechamento da peça, a partir do corte feito no c. 77 (letra E de ensaio) na partitura final. Na parte inferior da figura há a anotação "Talvez uma menção à The unanswered question do Charles Ives: tema da questão". Ives cria nesta peça, através de três camadas de eventos musicais, uma simbologia repleta de metáforas: um fundo constante realizado pelas cordas, um tempo alongado que ele vincula ao "silêncio dos Druídas, que não sabem, veem ou escutam nada"; uma melodia de trompete que se repete, a "pergunta perene sobre a existência"; algumas respostas do quarteto de sopros feitas após as reiterações da pergunta do trompete, como "tentativas que lutam para responder à pergunta", sempre sem sucesso ${ }^{33}$.

\footnotetext{
31 Arnie Cox (2011) defende a hipótese das "imagens miméticas motoras" (mimetic motor imagery), a qual tem como base o entendimento de que a experiência musical é internalizada mental e corporalmente e que muito de nossa compreensão musical vem de uma empatia que envolve a imaginação de estarmos fazendo os sons aos quais ouvimos. Dentro desta hipótese, a subvocalização é algo relevante. No mesmo artigo de Cox (passim) há também considerações sobre a imaginação mental da ação motora, questão importante e muito presente na construção das gestualidades ao longo da peça, principalmente entre os cc. 45-76.

32 Original: "Mimetic subvocalization includes any motor imagery and motor activation related to the vocal musculature. Bear in mind that it need not be intentional or conscious, and it can be very much like singing along or only indirectly like singing, involving simply exhaling in time $[\ldots .$.$] , or various kinds of exertions in the throat, and/or exertions of the tongue and/or lips".$

33 É possivel conferir descrições de The unanswered question em diversas fontes, tais quais: http://www.musicweb-international.com/ ives/WK_Unanswered_Question.htm ou https://charlesives.org/question-better-answer. (Ambos acessados em: 3 mar. 2020).
} 


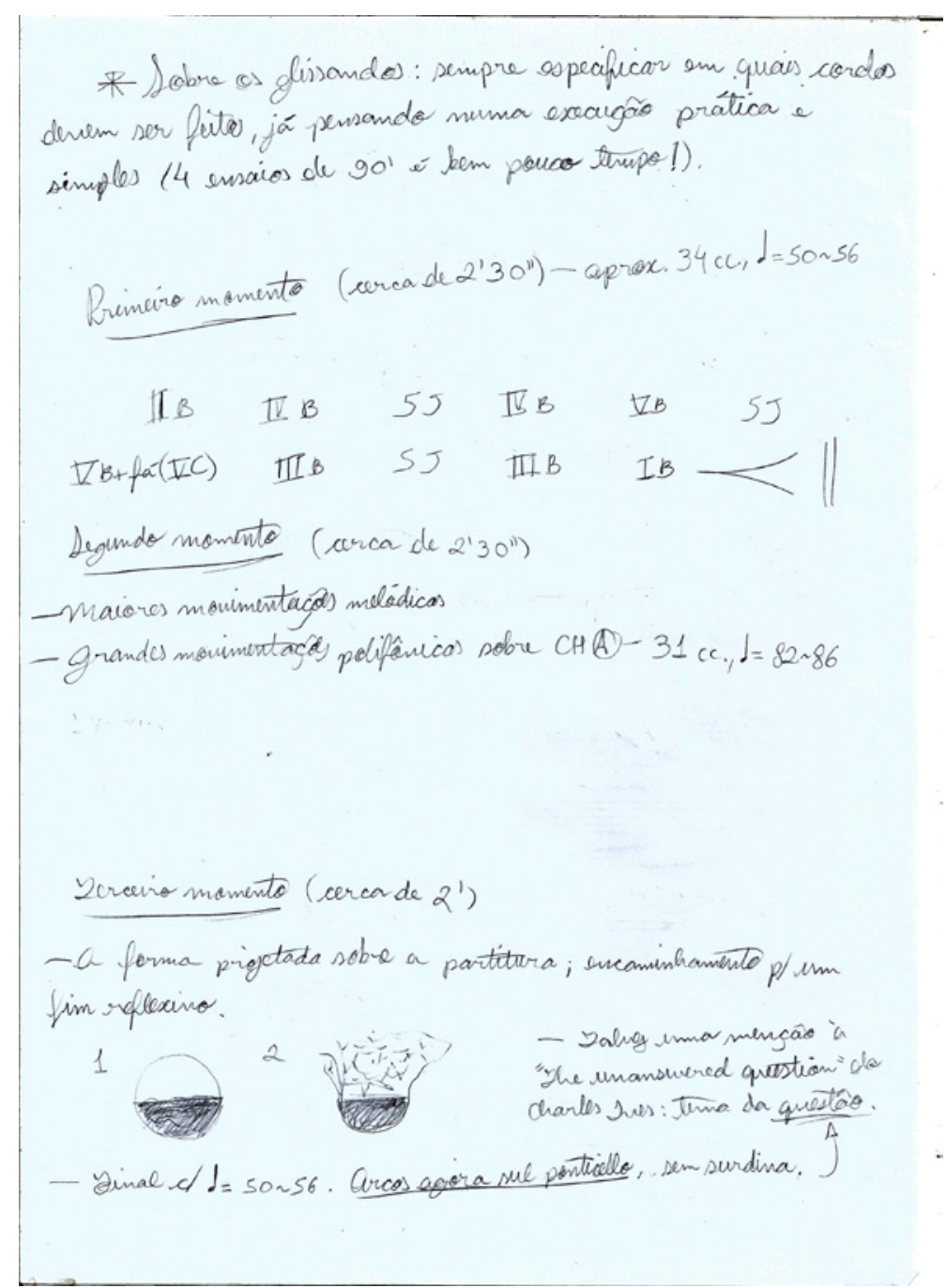

Fig. 11: Planejamento formal geral da peça, acompanhado de observações pertinentes sobre cada momento ${ }^{34}$.

A menção a The unanswered question não foi utilizada, mas acredito que o afeto desta obra de lves, que admiro em vários aspectos, esteve também presente no processo criativo. Encontro inclusive correspondências entre a proposta poética da peça de Ives e o final de $A$ escuridão, o corpo vermelho e o fascínio. Enquanto na primeira há uma pergunta que se repete e nunca encontra uma resposta - por fim terminando em silêncio -, na segunda há um material melódico que é revisitado constantemente e que ao final (no solo do violino I) termina numa frase sem uma conclusão, um decrescendo lento também em direção ao silêncio.

A própria proposta de não encontrar uma resposta definitiva, de viver a questão sem chegar a uma conclusão, diretamente ligada à poética de The unanswered question (cf. por exemplo os dois links da nota de rodapé no 33), esteve presente do início ao fim do período de escritura aqui relatado.

\footnotetext{
34 Acima na figura, a observação " 4 ensaios de 90' é bem pouco tempo!" se refere ao fato de que, segundo o edital do concurso, as três peças deveriam ser levantadas nestes quatro ensaios, havendo então quatro ensaios de 30 minutos para cada uma. Mas, ao longo do período de preparação do concerto de estreia, os maestros Gil Jardim e Enrico Ruggieri viabilizaram um remanejamento da quantidade de tempo de ensaio, havendo assim tempo suficiente para preparar todas peças sem problemas.
} 
Havia uma exigência do edital de não fazer uma peça demasiadamente longa (a duração total deveria ter por volta de 5 a 8 minutos). Havendo essa condição, foi prático pensar no desenrolar formal da peça com antecedência. O prazo para terminar a composição (dois meses) também não era grande, levando em conta que havia várias atividades paralelas à sua escritura; a utilização do tempo de composição deveria ser planejada para que não houvesse o risco de não terminar a partitura a tempo. Por conta disso, apesar de não ser um costume, optei por, após os primeiros rascunhos e testes, fazer um esqueleto formal prévio, mesmo que ele pudesse ser contestado e alterado posteriormente. A demanda por um processo relativamente rápido me fez usar ferramentas que lidavam diretamente com esse requisito.

Busquei fazer com que os primeiros 2/3 (aproximadamente) da duração total fossem dois grandes arcos formais de crescendos: o primeiro deles abrange os cc. 1-35, o segundo, os cc. 36-76 (cf. a partitura nos anexos). Ambos os arcos formais iniciam em dinâmicas menores e paulatinamente alcançam fortes intensidades e maiores movimentações, desaguando em ápices de energia. Por outro lado, as maneiras como cada um dos crescendos acontecem são bastante diferentes entre si.

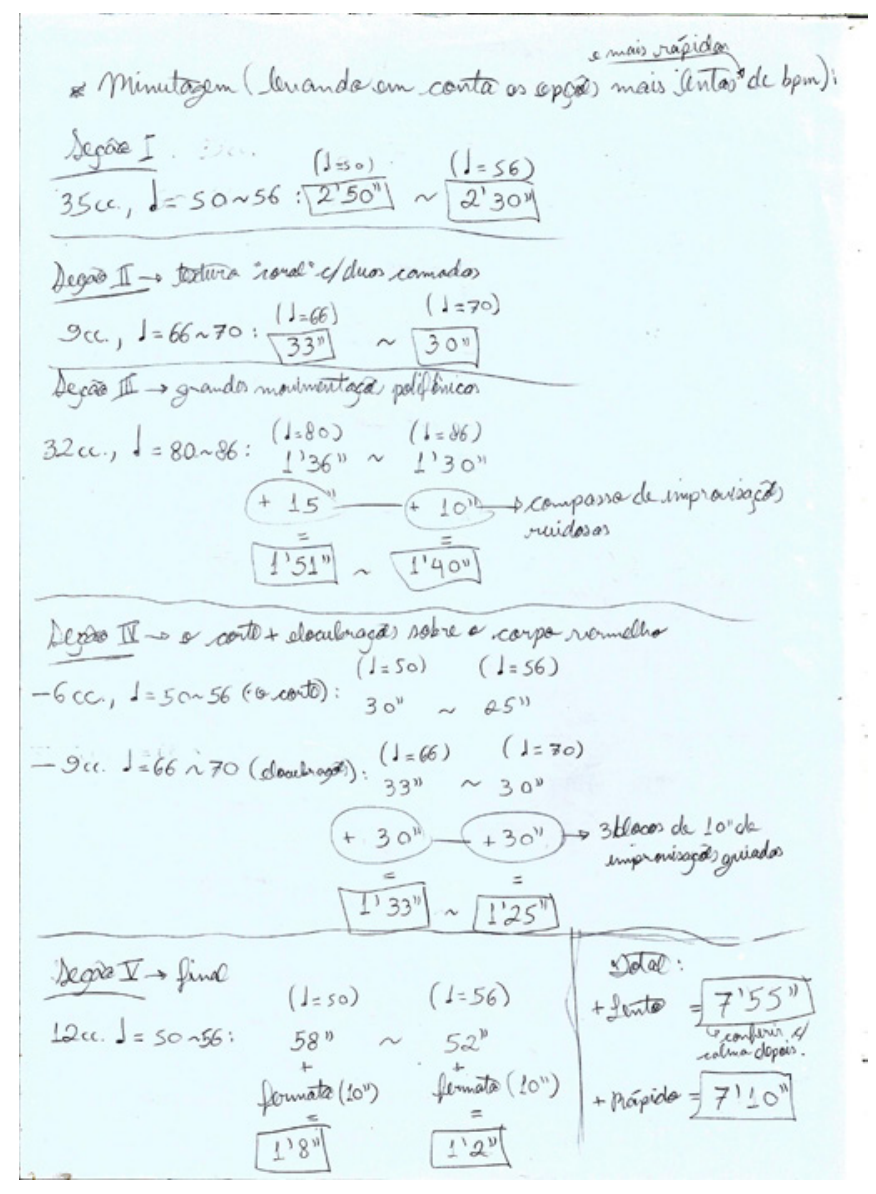

Fig. 12: Planejamento formal resumido com foco na minutagem, feito num estágio mais avançado da escritura, de modo que, em vez de haver três divisões gerais da forma, agora há cinco. Foram pensadas as durações tanto com as opções de andamentos mais rápidos quanto com as mais lentas. 
A definição formal neste aspecto veio em parte da própria pintura: quando contemplamos uma obra pictórica, os olhos não abarcam o todo simultaneamente. Em suas aulas de composição, Silvio Ferraz observa que a arte pictórica, apesar de ser taxada como uma forma artística "sem tempo" (em oposição à música ou ao teatro, por exemplo), possui, sim, diversas formas de tempo em si. Os olhos precisam caminhar pela tela, há sentidos pelos quais esse caminhar se dará, há ritmos naquilo que se vê, há sensações temporais várias envolvidas ${ }^{35}$.

Com relação à visualização da pintura de Tomie Ohtake, reparei em mim uma tendência a olhar o corpo vermelho de cima para baixo e de baixo para cima, mas raramente da esquerda para a direita ou vice-versa. Claro que esse movimento vertical não se dava de maneira estrita, pois os olhos não são como um par de scanners, e, ao longo de uma contemplação da pintura, eles também podem fazer várias caminhadas caóticas pela tela. Mas havia uma tendência a olhar o corpo vermelho num sentido mais vertical. Seja isso algo comum a todos ou não, achei uma questão curiosa que poderia ser explorada ${ }^{36}$.

Os primeiros 2/3 da peça foram formalmente pensados como dois crescendos que fazem uma analogia (descompromissada, que não necessariamente devesse ser clara aos ouvintes ou a quem fosse analisar a partitura) a dois exames do corpo vermelho de baixo para cima, como se, após o primeiro exame, a pessoa que vê decidisse refazer o mesmo caminho, mas prestando atenção a outras questões da pintura. Não foi algo pensado de modo rígido, mas, sim, uma sugestão que acabou tomando corpo. Isto não quer dizer que os primeiros 2/3 da peça sejam apenas relacionados ao corpo vermelho, sem levar em conta outros pontos, como a escuridão, por exemplo. Na verdade, inúmeros aspectos se mesclam em várias dimensões, de modo que não seria nem útil nem possível separar exatamente o que da pintura estaria em jogo em cada pedaço da música. Há alguns pontos com maior clareza de intenção, dos quais explico aqui uma parte.

Já a cisão entre os cc. 76 e 77 apresenta uma relação mais clara com a imagem, onde há um corte ${ }^{37}$ entre um tutti caótico em fortississimo e um tutti estático em subito piano. O corpo vermelho, se visto de baixo para cima, cresce continuamente até alcançar seu ápice e, após isso, some. O mesmo ocorre com a música neste trecho.

A exploração do contraste abrupto se dá precisamente ao final de cada um dos dois crescendos formais explicados logo acima, precisamente entre os cc. 35 e 36 (primeiro corte) e 76 e 77 (segundo corte). Estes dois momentos de cisão dialogam com a expressividade com que o corpo vermelho deixa de estar presente na metade superior da imagem; o corpo vermelho cresce e é interrompido de maneira cabal ${ }^{38}$. Edson Zam-

\footnotetext{
35 Conforme conteúdo apresentado na disciplina "Escritas do Som, do Gesto e do Tempo na Música Atual", oferecida no $2^{\circ}$ semestre de 2019 no Departamento de Música da ECA/USP.

36 Por outro lado, é interessante apontar que a própria busca por ter consciência sobre o caminho feito pelos olhos também me fez questionar a naturalidade daquilo que observava (o movimento dos olhos). Não sei se de fato meus olhos fariam esse caminho se eu não buscasse ter consciência sobre eles.

37 Cf. Ferraz (2015) para um estudo aprofundado sobre o tema do "corte".

38 Há na pintura uma nuance que sugere um certo sombreamento antes do corte, mas o afeto da interrupção me pareceu muito mais forte e presente do que o da gradação.
} 
pronha também explica que por meio do corte é possível sair do terreno dos estereótipos $^{39}$, pois,

[no corte,] embora as unidades também sejam reconhecíveis, elas se sucedem uma após as outras de modo não estereotipado. [...] Da mesma forma como é o espectador quem constrói a narrativa a partir da sucessão de cortes no cinema, é o ouvinte quem constrói as conexões entre os eventos musicais que se sucedem. O corte torna-se um forte elemento de rompimento das relações estereotipadas, principalmente quando as partes que se sucedem não justificam a conexão entre elas. (ZAMPRONHA, 2000, p.261).

Zampronha (2000) organiza quatro estratégias básicas para realizar um rompimento ou diluição do estereótipo: 1) Fragmentação (p.261-264), onde a saturação da escrita ou sua indeterminação (duas opções opostas) são vias possiveis, a presença de cortes ou usos metafóricos baseados em processos fragmentários também; 2) Paralelismo (p.264-267), quando há duas ou mais camadas sonoras distintas e inarmônicas em sobreposição, cada uma usando um sistema de representação próprio; 3) Distributividade (p.268-269), onde diversos centros ocorrem simultaneamente, mas num mesmo sistema de representação, ou seja, quando os diferentes aspectos da escrita passam a ser centros em si mesmos. A polifonia de centros das Sequenze de Berio é um exemplo; 4) Digressão (p.269-270), que é a introdução de um ou mais sistemas de representação dentro de outros. Uma seção de notação proporcional seguida de uma partitura grafista, por exemplo.

Os dois momentos de improvisação de $A$ escuridão, o corpo vermelho e o fascínio são tentativas simples de lidar com o quarto item organizado por Zampronha, de modo que a inserção feita é a de uma guia geral das sonoridades globais desejadas (descrição verbal geral do evento que se espera gerar) em diálogo com representações visuais de natureza própria à partitura (os sinais em cada pauta indicando de maneira geral os gestos a serem feitos por cada grupo).

Quando Zampronha (2000, p.73-95) organiza critérios tipológicos para classificarmos diferentes formas de notação, uma das camadas de avaliação é:

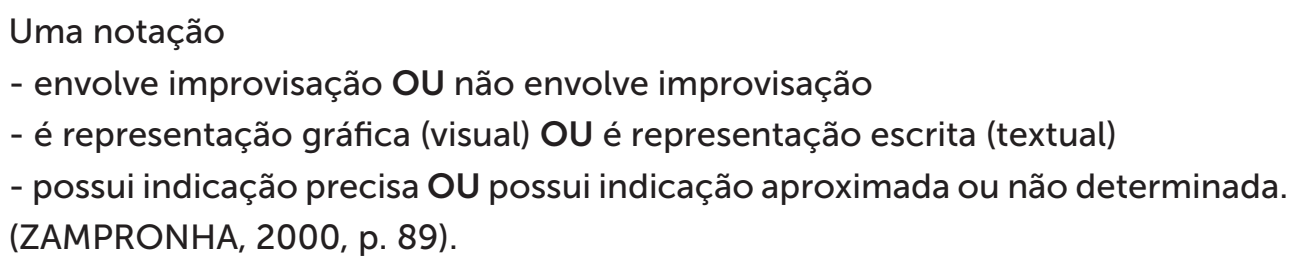

Nestes quesitos vemos que os trechos improvisatórios da partitura possuem qualidades opostas a todo o restante da partitura.

Há diversas veredas possíveis quanto ao tratamento dado ao legado teórico-estético que temos. Há compositores e compositoras utilizando tanto solfejos de notas musicais quanto solfejos que não possuem vínculo algum com a escuta melódica. Neste

Cf. Zampronha (2000) para diversas considerações sobre os estereótipos no âmbito da escrita musical. 
último caso, o pentagrama - suporte criado inicialmente sobre a hierarquia melódico-rítmica - precisa ser manipulado a favor de outra finalidade. Desta forma, é possível que haja qualidades perceptivas que não sejam representadas adequadamente através da partitura (SMALLEY, 1997, p.109), fazendo com que certas soluções sejam necessárias, como foi o caso nas seções de improvisos guiados.

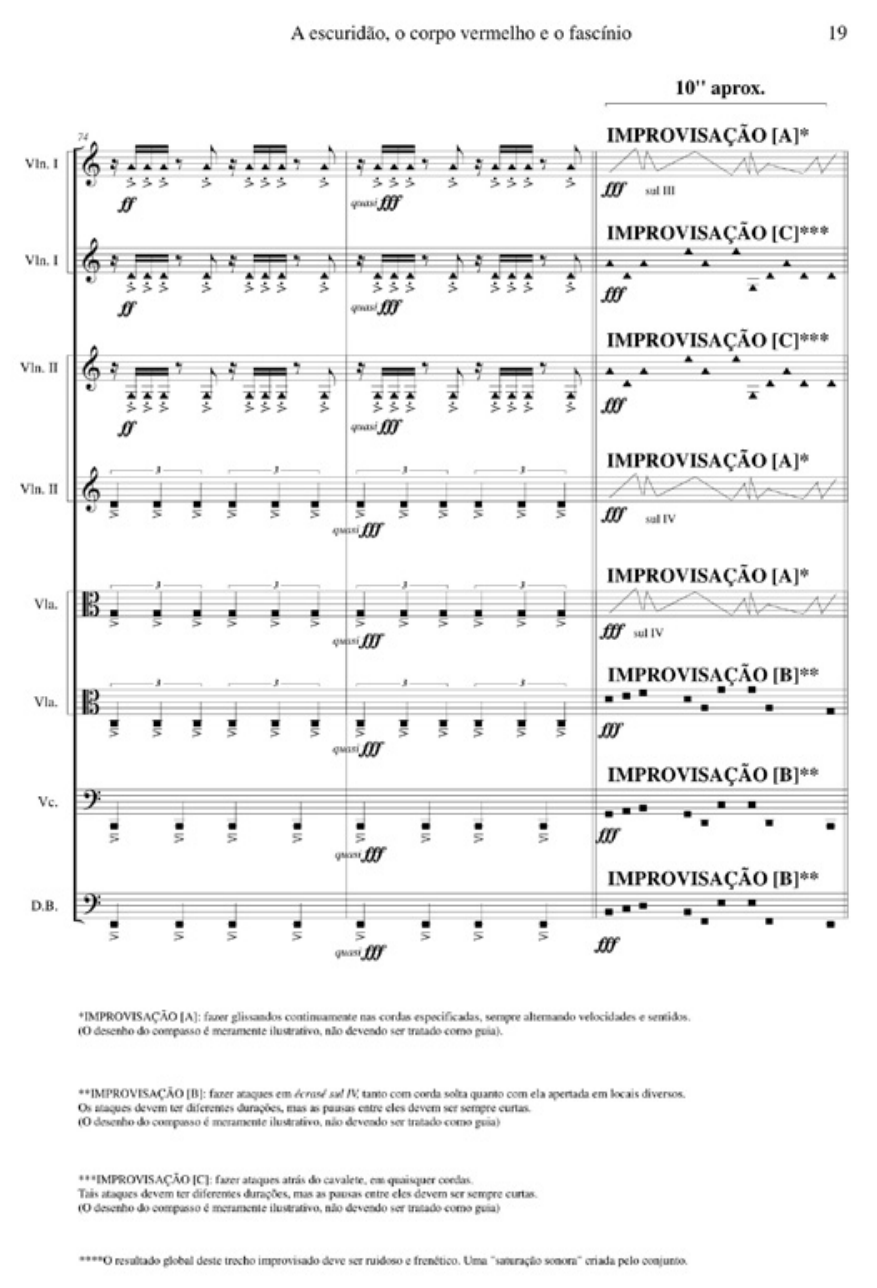

Fig. 13: A escuridão, o corpo vermelho e o fascínio (cc. 74-76). No c. 76, juntamente à alteração de notação, foram colocadas descrições textuais das ações a serem realizadas.

\section{$\diamond \diamond$}

Sobre a letra $F$ (que abrange os compassos 84-95), esta foi pensada como uma tentativa "retórica" de colocar uma pergunta que me surgiu ao longo do processo: o corpo vermelho aparenta ser um corpo celeste. E, se o fosse, isto a priori implicaria uma forma total esférica, da qual apenas veríamos a metade por conta do ângulo da luz. Mas poderia ser outra coisa também... Não que fosse importante definir uma representação 
para a pintura, pois acho que a essência dela não reside aí na representação; mas a inquietação da pergunta é que me interessou.

Se olharmos panoramicamente a página 22 da partitura (iniciando na letra de ensaio F), veremos que se forma um "desenho redondo" dividido em duas metades (sistemas superior e inferior), algo remetendo à ideia de um todo circular ou esférico - ironicamente, uma representação visual. Na página 23, temos a metade inferior repetindo a mesma estrutura (com dinâmica variada e agora com tremolo), mas a metade de cima é um improviso. É como se o improviso carregasse uma metáfora da pergunta "O que se esconde nesta escuridão da parte superior?", mas sem chegar a uma resposta.

A carga gestual dos cc. 84-89 e 93-95 em realidade é consequência desse recurso "retórico" de escrita, uma busca por colocar a pergunta numa forma de "metáfora-partitura".

Como maneira de pôr sugestões afetivas na própria partitura, cada seção formal tem um título que faz referência - afetivamente - à pintura. São eles, consecutivamente: "Escuridão e seus mistérios" (cc. 1-35), "Inquietações em vermelho" (cc. 36-76), "A cisão" (cc. 77-83), "Indagações sobre o corpo vermelho" (cc. 85-95) e "O desconhecido impenetrável" (cc. 96-107). Esses títulos dão pistas sobre o processo de criação, pois de fato se relacionam com ideias que, apesar de abstratas, estavam presentes em forma de sugestões, sensações. E, além de tornar mais claras certas intenções poéticas, acredito que eles sirvam como um impulso à própria interpretação e à escuta.

Conforme dito, os primeiros 2/3 (aproximativamente) da peça são dois crescendos - os dois primeiros títulos se referem a tais. Se observarmos a quantidade de compassos de cada seção, veremos que as duas primeiras seções possuem grande quantidade de compassos, enquanto as outras são bem menores. $O$ último terço foi planejado mais como um fio condutor que une um conjunto de devaneios, estes um pouco mais difusos. Após dois arcos formais bem lineares, acontecem três pequenos arcos mais concisos (os três últimos títulos), um se transformando no outro organicamente, mas sem se fixar muito tempo numa única configuração.

Por fim, quis terminar com algo que vai al niente, que some aos poucos. Queria um fechamento melódico para a peça, uma melodia que remetesse ao primeiro solo da viola e que conversasse consequentemente com as várias melodias do decorrer da peça. Após ressoar, queria que essa linha fosse se distanciando e sumisse sobre uma sonoridade "enevoada" que também se desvanecesse pouco a pouco, sem que se soubesse ao certo onde estaria a fronteira entre os últimos sons mais sutis e o silenciar dos instrumentos.

\section{Observações finais}

Diferentes pontos do processo foram relatados e discutidos. Infelizmente não seria possível relatar apenas num artigo todos os pontos desta rica experiência, que também 
engloba a parte prática dos ensaios, da troca com os músicos da Ocam e das conversas com os regentes e os outros compositores.

O contexto de uma composição não se restringe a papel, lápis, computador e instrumentos/vozes. Pelo contrário, ele abarca redes de entrelaçamentos e de corpos que estão muito além do que se encontra na própria partitura. Paulo Rios Filho - cuja pesquisa sobre a composição, juntamente à sua produção composicional, refletem constantemente as potências da ação criativa -, reconhecendo a profundidade das relações existentes num tal contexto, discorre:

[...] a reciprocidade entre compositor e obra, além de ser múltipla "em si mesma", envolve necessariamente também a participação de outros corpos. Como falar de reciprocidade em composição sem assumir o nível dos fluxos entre compositor e ouvinte - poiesis/estesis? Entre compositor e intérprete - concepção/ performance? Entre a obra e o ouvinte - codificação/descodificação? Ou a obra e o músico...? O músico e o ouvinte? Composição parece envolver tudo isso a uma só vez, toda essa zona difusa de relação entre corpos que já são, eles próprios, co-formados ao longo de um complexo de relações "internas". (RIOS FILHO, 2015, p.18).

Disso infere-se que a "partitura finalizada" é certamente fruto de um processo, mas não é o processo em si. Mais do que a confecção de uma "obra", tal processo vibra em muitos âmbitos, alguns destes gerando uma partitura, outros gerando outras formas de resultado. Mas o que esta colocação muda em termos práticos?

A meu ver, isto faz com que se quebre a concepção de "processo em direção à obra terminada", noção sobre a qual Rios Filho também expõe:

Trata-se de enxergar o processo criativo em si e não voltado a um ponto de chegada, aquele da partitura ou da forma "final". E isso simplesmente porque não existe algo como a "partitura" ou a "forma final" - partitura e forma seguem sempre se refazendo, ao longo de uma série de revisões, ao longo de uma série de performances, análises, audições. A obra não é uma forma, objeto autocontido; não é uma partitura, não é um produto ou o resultado do processo criativo que se desenrolou atrás, na história de formação do seu corpo. Nem o processo criativo, por outro lado, é um percurso administrado pelo sujeito criador, que imprime suas escolhas de forma cumulativa até a chegada da "forma final", do "produto", a "obra", a linha do horizonte de vida da criação em movimento, a morte do processo criativo. (RIOS FILHO, 2015, p.24).

Olhando por esse prisma, é possível que uma peça ressoe em outra, que ideias de um momento vibrem em outro, ou mesmo que a busca por uma constante originalidade, pela inovação constante, seja questionada. Há aqui uma partitura que pode ser considerada "finalizada", mas ela não é algo iniciado e encerrado em si próprio ${ }^{40}$.

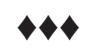


Escrever uma peça musical a partir da pintura Sem título (1987) de Tomie Ohtake se mostrou um desafio imensamente enriquecedor, tanto do ponto de vista técnico quanto pelos processos de reflexão. Em vez de buscar juízos de certo e errado, a investigação aprofundada sobre a pintura revelou inúmeras possibilidades de atravessamentos e pontos de vista. Este texto mostrou algumas poucas dessas infinitas possibilidades, as quais levaram a soluções de escrita específicas. Como fruto deste processo surgiram consequências formais, ferramentais e perceptivas, que deram paulatinamente corpo a um discurso poético preenchido de afetos que ressoam da pintura.

É possível observar que ao longo do decurso somaram-se diversas outras fontes além da pintura em si, tais quais outras composições, outras pessoas que refletem o fazer artístico, outras pesquisas, outros atravessamentos... De fato não imagino um processo que se encerre em si próprio e creio que, no mundo interno de cada pessoa que cria, os cruzamentos e ressonâncias ocorrem em várias direções e dimensões, numa troca mais rica do que seria possível expor num discurso sucinto e linear.

Partilhar experiências de um ato criativo é uma forma de gerar trocas de ideias e aprendizados entre pessoas que se interessem pelo assunto, um início para diversas outras discussões ligadas à criação artística entrarem em jogo. Espero que o presente relato seja útil e prazeroso para quem o ler.

\section{Referências}

\section{Imagens}

SZLAVNICS, Chiyoko. Gradients of detail. 2005. 1 figura. Disponível em: http://www. chiyokoszlavnics.org/dwg_row2_05.html.

\section{Partituras musicais}

HAYDN, Joseph. Sinfonia no 47. 1772. 1 partitura. Disponível em: https://imslp.org/wiki/ Symphony_No.47_in_G_major,_Hob.I:47_(Haydn,_Joseph).

\section{Sites}

ANNA CLYNE. Orchestra. Disponível em: http://www.annaclyne.com/orchestra.

CHIYOKO SZLAVNICS. Disponível em: http://www.chiyokoszlavnics.org/welcome. html.

CLYNE, Anna. Night Ferry. 2012. Boosey \& Hawkes, [s. d.]. Disponível em: https://www. boosey.com/cr/music/Anna-Clyne-Night-Ferry/56273.

INSTITUTO TOMIE OHTAKE. Tomie Ohtake. Disponível em: https://www. institutotomieohtake.org.br/o_instituto/tomie_ohtake. 
THE UNANSWERED question: notes. Music Web International, [s. d.]. Disponível em: http://www.musicweb-international.com/ives/WK_Unanswered_Question.htm

\section{Gravações musicais}

OCAM - ORQUESTRA DE CÂMARA DA ECA/USP. Segredos de Vera Cruz: música popular brasileira para gaita e orquestra. 2019. Disponível em: https://open. spotify.com/album/5XBIPDkn9pJGYELvQO4JGJ (Acesso em: 9 maio 2020) e https://www.youtube.com/watch?v=wj3FGsmaJdQ\&list=OLAK5uy_lo9e336nm_ MUQcA3OD5u7sMJgAeLPpSVk (Acesso em: 8 maio 2020).

OCAM - ORQUESTRA DE CÂMARA DA ECA/USP. Sons sobre tons: criações musicais sobre ideias visuais. 2019. Disponível em: https://open.spotify.com/ album/ObzzycQbWE3QJCebXfRP7D (Acesso em: 15 mar. 2020) e https://www. youtube.com/playlist?list=OLAK5uy_mmp2etxygakYVzhKarlpsC1rDhZMRssMo (Acesso em: 15 mar. 2020).

\section{Vídeos}

CLYNE, Anna. Night Ferry with the Chigado Symphony Orchestra. Disponivel em: https://www.boosey.com/podcast/Anna-Clyne-Anna-Clyne-Night-Ferry-with-theCSO/13272. Acesso em: 7 maio 2020.

CLYNE, Anna. Night Ferry. 2012. Disponível em: https://www.boosey.com/cr/music/ Anna-Clyne-Night-Ferry/56273. Acesso em: 7 maio 2020.

YAMASAKI, Tizuka. Tomie. 2015. Disponível em: https://www.institutotomieohtake.org. br/o_instituto/tomie_ohtake (Acesso em: 15 mar. 2020) e https://www.youtube.com/ watch?v=x_cA_c6UcQg\&feature=emb_logo (Acesso em: 15 mar. 2020).

\section{Referências bibliográficas}

BRINDLE, Reginald Smith. The new music: the avant-garde since 1945. 2. ed. New York: Oxford University Press, 1987.

COX, Arnie. Embodying music: principles of the mimetic hypothesis. Music Theory Online, v. 17, n. 2, 2011.

DELALANDE, François. Le son des musiques: entre technologie et esthétique. Paris: INABuchet/Chastel, 2001.

FERRAZ, Silvio. Livro das sonoridades: notas dispersas sobre composição. Rio de Janeiro: 7 Letras, 2005. 
FERRAZ, Silvio. Tatuagens. In: FERRAZ, Silvio. Notas, atos, gestos: relatos composicionais de Marisa Rezende, Silvio Ferraz, Denise Garcia, Fernando lazzetta, Marcos Lacerda, Rodolfo Caesar, Rogério Costa. Rio de Janeiro: 7 Letras, 2007. p. 91116. (Coleção Trinca Ferro).

FERRAZ, Silvio. Kairos: ponto de ruptura. Ouvirouver (on-line), v. 11, n. 1, p. 34-52, 2015.

FICAGNA, Alexandre Remuzzi. Entre o visual e o sonoro: a composição por imagens. Tese (Doutorado) - Universidade Estadual de Campinas, Campinas, 2014.

KLEE, Paul. Pedagogical Sketchbook. Traduzido do alemão para o inglês por Sibyl Moholy-Nagy. London: Faber and Faber, 1984.

LIMA, Rodrigo. Da nota ao Som: explorando territórios harmônicos. Dissertação (Mestrado) - Universidade Estadual de Campinas, Campinas, 2009.

MANI, Pedro Yugo; FERRAZ, Silvio. A obra Quando se muda a paisagem..., de Rodrigo Lima, como um processo de solfejos. Revista DEBATES: Cadernos do Programa de Pós-Graduação em Música da Unirio, n. 23, p. 28-76, 2019.

PENHA, Gustavo. Entre escutas e solfejos: afetos e reescrita crítica na composição musical. Tese (Doutorado) - Universidade Estadual de Campinas, Campinas, 2016.

RIOS FILHO, Paulo. Um compor-emaranhado: composição, teoria e análise ao longo de linhas. Tese (Doutorado) - Universidade Federal da Bahia, Salvador, 2015.

SMALLEY, Denis. Spectromorphology: explaining sound-shapes. Organised Sound, v. 2, n. 2, p. 107-126, 1997.

SOLOMOS, Makis. De la musique au son: L'émergence du son dans la musique des XXeXXIe siècles. Rennes: Presses universitaire de Rennes, 2013. Versão do autor (utilizada no presente artigo) disponível em: https://hal.archives-ouvertes.fr/hal-00769893. Acesso em: 7 maio 2020.

SWAFFORD, Jan. A question is better than a answer. Medford: Charles Ives Society, [s.d.]. Disponível em: https://charlesives.org/question-better-answer. Acesso em: 3 mar. 2020.

SZLAVNICS Chiyoko. Opening ears. The intimacy of the detail of sound. Filigrane. Musique, esthétique, sciences, société, n. 4, p. 37-58, 2006.

ZAMPRONHA, Edson. Notação, representação e composição: um novo paradigma da escritura musical. São Paulo: Annablume, Fapesp, 2000. 